THE ACUTE EFFECTS OF AIR BLAST ON PULMONARY FUNCTION

IN DOGS AND SHEEP

\author{
Technical Progress Report
}

on

Contract No. DA-49-146-XZ-372

Edward G. Damon, John T. Yelverton, Ulrich C. Luft, Kabby Mitchell, Jr., and Robert K. Jones.

March 1970

THIS WORK, A PHASE OF INVESTIGATIONS DEALING WITH THE BIOLOGICAL EFFECTS OF BLAST FROM BOMBS, WAS SUPPORTED BY THE DEFENSE ATOMIC SUPPORT AGENCY OF THE DEPARTMENT OF DEFENSE.

PREPARING AGENCY Lovelace Foundation for Medical Education and Research Albuquerque, New Mexico 


\section{DISCLAIMER}

This report was prepared as an account of work sponsored by an agency of the United States Government. Neither the United States Government nor any agency Thereof, nor any of their employees, makes any warranty, express or implied, or assumes any legal liability or responsibility for the accuracy, completeness, or usefulness of any information, apparatus, product, or process disclosed, or represents that its use would not infringe privately owned rights. Reference herein to any specific commercial product, process, or service by trade name, trademark, manufacturer, or otherwise does not necessarily constitute or imply its endorsement, recommendation, or favoring by the United States Government or any agency thereof. The views and opinions of authors expressed herein do not necessarily state or reflect those of the United States Government or any agency thereof. 


\section{DISCLAIMER}

Portions of this document may be illegible in electronic image products. Images are produced from the best available original document. 


\title{
THE ACUTE EFFECTS OF AIR BLAST ON PULMONARY FUNCTION IN DOGS AND SHEEP
}

Edward G. Damon, John T. Yelverton, Ulrich C. Luft, Kabby Mitchell, Jr., and Robert K. Jones

\section{Technical Progress Report}

on

Contract No. DA-49-146-XZ-372

\section{THIS WORK, A PHASE OF INVESTIGATIONS DEALING WITH THE \\ BIOLOGICAL EFFECTS OF BLAST FROM BOMBS, WAS SUPPORTED BY THE DEFENSE ATOMIC SUPPORT AGENCY OF THE DEPARTMENT OF DEFENSE.}

(Reproduction in whole or in part is permitted for any purpose of the United States Government.)

\author{
PREPARING AGENCY \\ Lovelace Foundation for Medical Education and Research \\ Albuquerque, New Mexico
}

March 1970 

This report presents the results of studies on the relationship between air-blast injury and impairment of pulmonary function in dogs and sheep. Specifically, impairment of pulmonary function was measured in terms of alterations in the venous-arterial shunt, ineffective alveolar ventilation, and blood gas tensions.

The findings may be of interest to those involved in the analysis of weapons effects or in industrial or military medicine.

This study is part of a broad program in the field of Blast and Shock Biology, the aims of which are the accurate prediction of hazards from explosions and the development of a sound basis for the prognosis and treatment of blast injuries. 
Pulmonary function tests were conducted before and after exposure of animals to air blasts produced in shock tubes or by high explosives. Pressure-time measurements were made with piezoelectric pressure transducers during each air-blast exposure. Blood samples were obtained without anesthesia from an indwelling arterial catheter. The blood $\mathrm{P}_{\mathrm{O}_{2}}, \mathrm{P}_{\mathrm{CO}_{2}}$, and $\mathrm{pH}$ and the end-tidal and mixed expired $\mathrm{CO}_{2}, \mathrm{O}_{2}$, and $\mathrm{N}_{2}$ gas concentrations were measured for subjects breathing air and oxygen. There were increases in the alveolar-arterial $\mathrm{O}_{2}$ differences $(\mathrm{A}-\mathrm{a})_{\mathrm{O}_{2}}$, and venous admixture $(\stackrel{\circ}{\mathrm{Q}} / \stackrel{\circ}{\mathrm{Q}})$ which generally correlated with the extent of blast-induced lung damage. Calculations indicated that most of the increase in $(\mathrm{A}-\mathrm{a}) \mathrm{O}_{2}$ for subjects breathing air could be attributed to the increase in Qs/Q alone. The threshold for lung injury resulting in increased venous admixture in sheep was about 20 psi for reflected overpressures of "long" duration. Pressures above 43 psi usually caused severe lung damage in which the venous-arterial shunt exceeded 30 percent of the cardiac output, a condition in which the arterial oxygen tension was below the level required for full saturation of the hemoglobin even with animals breathing pure oxygen. 


\section{ACKNOW LEDGMENTS}

The authors would like to acknowledge the able technical assistance of Messrs. David A. Byrne, Bill B. Daughtery, Allie Shaw, Charles S. Gaylord, and Glen L. Paxton in the Department of Comparative Environmental Biology and to express appreciation to Mmes. Treva J. Miller, Aida Elliott, and Wanda L. Deyo and others in the Department of Physiology who provided technical guidance and assistance in the analytical work.

Appreciation is expressed to Mrs. Maxine U. Thibert for editing and typing the manuscript and to $\mathrm{Mr}$. Takeshi Minagawa for assistance with the illustrations.

We would also like to express appreciation to Messrs. Wilmer R. Kerzee and Bill Garrett, and Mrs. Sherry Schluter for programming and conducting the calculations on the Burroughs B5500 electronic computer.

Finally, we would like to express sincere appreciation to Ernest $A$. Henderson, D. V.M., for veterinary surgical support in the development and refinement of techniques of implanting the arterial catheters according to procedures initiated by R. W. Dougherty, D. V. M., USDA Animal Disease Control Center, Ames, Iowa. 
The experimental work discussed in this manuscript was conducted according to the principles enunciated in the "Guide for Laboratory Animal Facilities and Care, " prepared by the National Academy of Sciences-National

Research Council. 


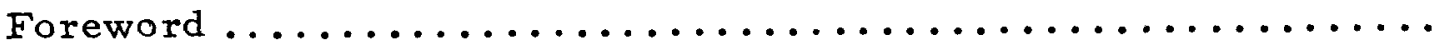

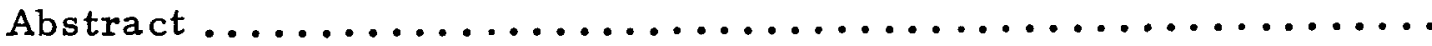

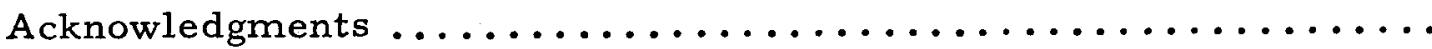

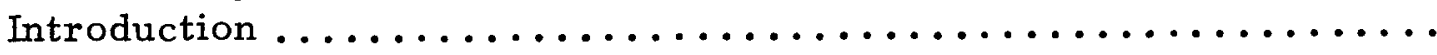

Methods

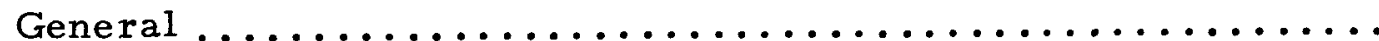

Animals.

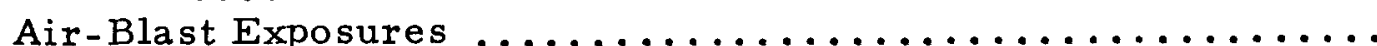

Sampling of Arterial Blood from Anesthetized Animals .....

Sampling of Arterial Blood Without Anesthesia ...........

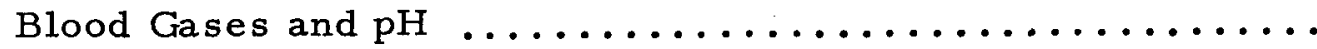

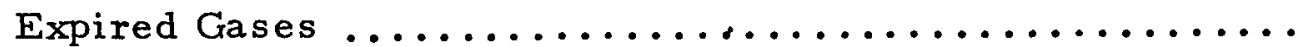

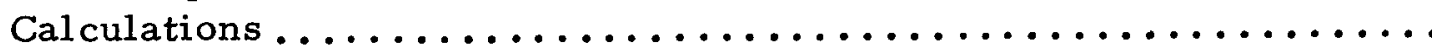

Alveolar Gas Tensions and Pulmonary Ventilation ..........

Venous-Arterial Shunt ........................

Breakdown of Causes of Alveolar-Arterial Oxygen

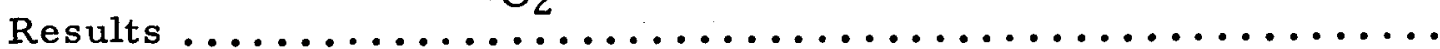

Differences $(A-a) O_{2}$ for Animals Breathing Air ........... 10

Venous-Arterial Shunt . . . . . . . . . . . . . . . . . .

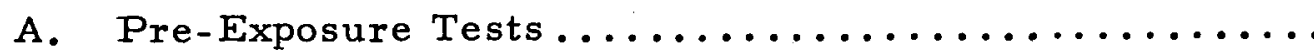

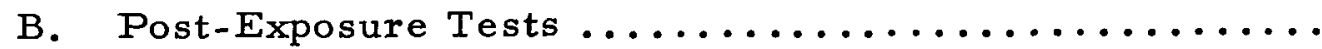

Respiratory Rate, $\mathrm{CO}_{2}$ Tension, and $\mathrm{pH}$ of the Arterial Blood... Minute Volume, $\mathrm{CO}_{2}$ Gradient, and Ineffective Alveolar .......

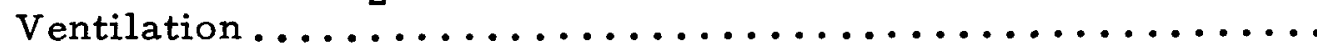

Oxygen Consumption, Carbon Dioxide Elimination, and

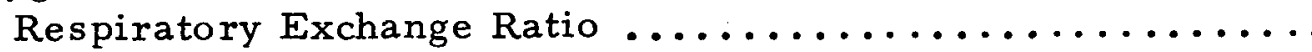

Discussion

\section{LIST OF FIGURES}

1. Typical pressure-time waveform recorded by a gauge mounted 6 inches upstream from the endplate of the 42-72 inch diameter shock tube

2. Cannulation of femoral artery for repeated sampling of a rterial blood in unanesthetized sheep ..............

3. Schematic of equipment for conducting pulmonary function tests on unanesthetized sheep................

4. Effects of air blast on venous-arterial shunt ( $\dot{Q} s / \dot{Q})$, arterial $\mathrm{O}_{2}$ tension $\left(\mathrm{P}_{\mathrm{a}_{2}}\right)$, and alveolar-arterial $\mathrm{O}_{2}$ gradient $(\mathrm{A}-\mathrm{a}) \mathrm{O}_{2}$ in sheep and dogs. 
5. Effects of air blast on venous-arterial shunt (Qs/Q), arterial $\mathrm{O}_{2}$ tension $\left(\mathrm{P}_{\mathrm{O}_{2}}\right)$, and alveolar-arterial $\mathrm{O}_{2}$ gradient $(\mathrm{A}-\mathrm{a}) \mathrm{O}_{2}$ in sheep and dogs $\ldots \ldots \ldots \ldots \ldots \ldots \ldots$

6. Effects of air blast on respiratory rate, $\mathrm{CO}_{2}$ tension $\left(\mathrm{P}_{\mathrm{CO}_{2}}\right)$, and $\mathrm{pH}$ of the arterial blood for animals breathing air ............................ 14

7. Effects of air blast on ventilation $\left(\dot{\mathrm{V}}_{\mathrm{I}}\right), \mathrm{CO}_{2}$ gradient $\left[(\mathrm{a}-\mathrm{E} . \mathrm{T}.) \mathrm{CO}_{2}\right]$, and ineffective alveolar ventilation

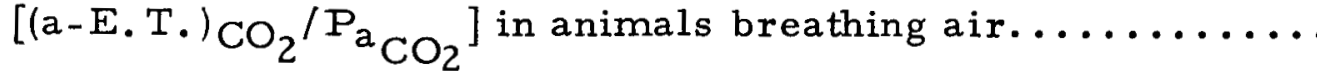

APPENDIX A

Abbreviations and Symbols.

APPENDIX B

Tabulated Data: Tables 1 through $7 \ldots \ldots \ldots \ldots \ldots \ldots \ldots \ldots \ldots \ldots$

APPENDDX C

Distribution........................ 


\section{THE ACUTE EFFECTS OF AIR BLAST \\ ON PULMONARY FUNCTION IN DOGS AND SHEEP}

Edward G. Damon, John T. Yelverton, Ulrich C. Luft, Kabby Mitchell, Jr., and Robert K. Jones

\section{INTRODUCTION}

The lungs are more susceptible to primary blast injury than other vital organs. Consequently, considerable attention has been devoted to the documentation of the extent and nature of lung-blast injuries resulting from various levels and conditions of blast exposure. ${ }^{1-9}$ To date, however, most of these have dealt only with the pathological alterations associated with air-blast damage. Studies of the physiological effects of blast on pulmonary function have been limited to investigation of the rate, depth, and rhythm of respiration; $;^{1-3,9-10}$ diaphragmatic action potentials; ${ }^{10}$ and lung compliance, respiration, and gas exchange in rabbits. 11,12

The cardiopulmonary system exchanges and transports respiratory gases by means of two pumps: an air pump (the pulmonary system) and a fluid pump (the cardiovascular system). Normally, the outputs of these two purnps, the cardiac output $(\stackrel{\circ}{Q})$ and the alveolar ventilation $\left(\dot{V}_{A}\right)$, a re coordinated in such a way as to result in an efficient system of gas exchange which maintains within narrow limits the $\mathrm{pH}, \mathrm{CO}_{2}$ content, and oxygen saturation of the blood. In lung-blast injury, the membranes separating the two systems are disrupted, resulting in hemorrhage into the air-containing spaces (alveoli, alveolar ducts, bronchioles, and bronchi) and may result in injection of air bubbles into the circulatory system. $1,4,8$ Until adequate compensation occurs in the surviving organism, such injuries might be expected to produce, among other effects, a mismatching of the outputs of the two pumps; i.e., aberrations in the $\dot{V}_{A} / \stackrel{\circ}{Q}$ ratios in 
various parts of the lungs. One might expect that some level of circulation would be maintained through damaged, nonventilated parts of the lungs, resulting in an admixture of venous blood with the oxygenated blood and similarly that there would be ventilation of parts of the lungs in which the pulmona ry circulation had been disrupted by blast injury which would be ineffective for gas exchange and would, therefore, constitute alveolar dead space ventilation. A fluid shift from capillaries to interstitial and alveolar spaces may also occur resulting in the development of pulmonary edema. In order to provide a sound basis for the intelligent prognosis and therapy of blast survivors and to provide data for prediction of the physiological effects of overpressures, there is a distinct need for an investigation designed to explore the relationship between the level of blast exposure and the resultant changes in functional efficiency of the cardiopulmonary system. Such information is also needed for proper interpretation of the effects of exposure to combinations of air blast and other environmental stresses.

Therefore, the following study was performed to investigate the acute effects of various levels of air-blast injury on pulmonary ventilation and gas exchange in sheep and dogs with major emphasis on changes produced in the venous-arterial shunt and attendant effects on the blood-gas parameters.

\section{METHODS}

\section{General}

The abbreviations and symbols used in the text are defined in Appendix A. The effects of air-blast injury on the venous-arterial shunt $\left(\stackrel{\mathrm{Q}}{\mathrm{s}} / \stackrel{\mathrm{Q}}{)}\right.$ ), alveolar-arterial $\mathrm{O}_{2}$ gradient $(\mathrm{A}-\mathrm{a}) \mathrm{O}_{2}$, arterial-alveolar (endtidal) $\mathrm{CO}_{2}$ gradient (a-A) $\mathrm{CO}_{2}$, alveolar dead space ventilation, oxygen tension $\left(\mathrm{P}_{\mathrm{a}_{2}}\right)$, carbon dioxide tension $\left(\mathrm{P}_{\mathrm{a}_{\mathrm{CO}}}\right)$, and arterial blood $\mathrm{pH}$ 
were investigated in sheep and dogs. Pulmonary function tests with and without anesthesia were conducted before and as soon as possible (usually within 30 minutes) after exposure to air blast. Each animal's pre-exposure test data served as its own controls.

\section{Animals}

Thirty-six young adult ewes and seven Beagles were utilized. The mean body weights were 42.2 and $8.2 \mathrm{~kg}$ for sheep and dogs, respectively. Twenty-seven of the sheep and six of the dogs were exposed to air blast. The rest of the animals were used as controls and to develop the pulmonary function test procedures.

Air-Blast Exposures

With the exception of three sheep exposed to blast from an air burst of a 64-1b spherical charge of TNT, all blast-response tests in this study were conducted in shock tubes. The ambient pressure at exposure was the local barometric pressure (12 psia). ${ }^{13}$ The sheep were exposed with their left sides against the endplate of a 42-72 inch diameter shock tube to "sharp"-rising reflected overpressures $\left(P_{f}\right)$ with durations ranging from 93 to $225 \mathrm{msec}{ }^{14,15}$ The dogs were exposed with their left sides against the endplate of a 24-40 inch diameter shock tube to reflected overpressures of 335 to $380 \mathrm{msec}$ duration. ${ }^{16}$ Each animal was secured to the endplate by means of a harness constructed of nylon webbing.

Pressure-time measurements were made during each test with piezoelectric pressure transducers. The pressure-time instrumentation has been previously described. ${ }^{14}$ Figure 1 presents a representative pressure-time waveform that is typical of those recorded by a gauge mounted side-on in the walls of the 6-ft shock tube directly above the back of the sheep.

Sampling of Arterial Blood from Anesthetized Animals Dogs were anesthetized with an intravenous dose $(25 \mathrm{mg} / \mathrm{kg})$ of 


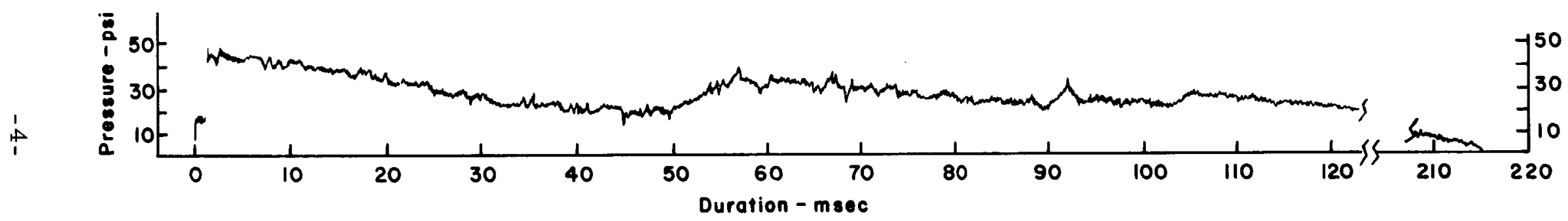

Figure 1. Typical pressure-time waveform recorded by a gauge mounted 6 inches upstream from the endplate of the 42-72-inch diameter shock tube. 
sodium pentobarbital. Atropine sulfate $(0.05 \mathrm{mg} / \mathrm{kg})$ and sodium secobarbital $(20 \mathrm{mg} / \mathrm{kg})$ were used for anesthesia in sheep.

An 18 gauge cournand arterial needle was inserted into the surgically exposed femoral or carotid artery. A plastic three-way stopcock with a rubber cap on its main outlet was mounted on the cournand needle. The dead space of a 2 or $5 \mathrm{cc}$ glass syringe fitted with a 20 gauge needle was filled with dilute heparin $(10 \mathrm{mg} / \mathrm{ml})$ and air-free blood samples were drawn by inserting the needle through the rubber cap on the stopcock. The syringe was capped with a Luer-Lok cap, placed in an ice bath and the blood usually analyzed within 1 to 5 minutes after sampling.

Sampling of Arterial Blood Without Anesthesia

Several techniques for sampling arterial blood without anesthesia were tried with varying degrees of success. ${ }^{17,18}$ The most successful procedure consisted of the insertion of a polyvinyl tube through the femoral artery into the caudal part of the aorta of the sheep (Fig. 2). This technique has been described in a separate report. ${ }^{19}$ Blood was drawn from carotid arteries in dogs.

In some sheep, the indwelling cannula remained functional for more than 140 days after surgery. The location of the cannula on the back of the animal was convenient for obtaining the arterial blood samples at the desired times during the pulmonary function tests. Blood samples from the cannula were drawn and processed as for anesthetized animals.

$\underline{\text { Blood Gases and } \mathrm{pH}}$

The $\mathrm{pH}, \mathrm{P}_{\mathrm{a}_{2}}$, and $\mathrm{P}_{\mathrm{a}_{\mathrm{CO}}}$ of the blood were measured with either an Instrumentation Laboratories Model 113-SI Ultra-Micro pH, $\mathrm{P}_{2}$, and $\mathrm{P}_{\mathrm{CO}_{2}}$ Blood Analyzing System, or a Beckman Model 160 Physiological Gas Analyzer with Modular Cuvette and oxygen macroelectrode. All three measurements were made at a temperature of $37^{\circ} \mathrm{C}$ and then corrected to the species body temperature $\left(39^{\circ} \mathrm{C}\right.$ for both sheep and dogs). ${ }^{20,21}$ The 


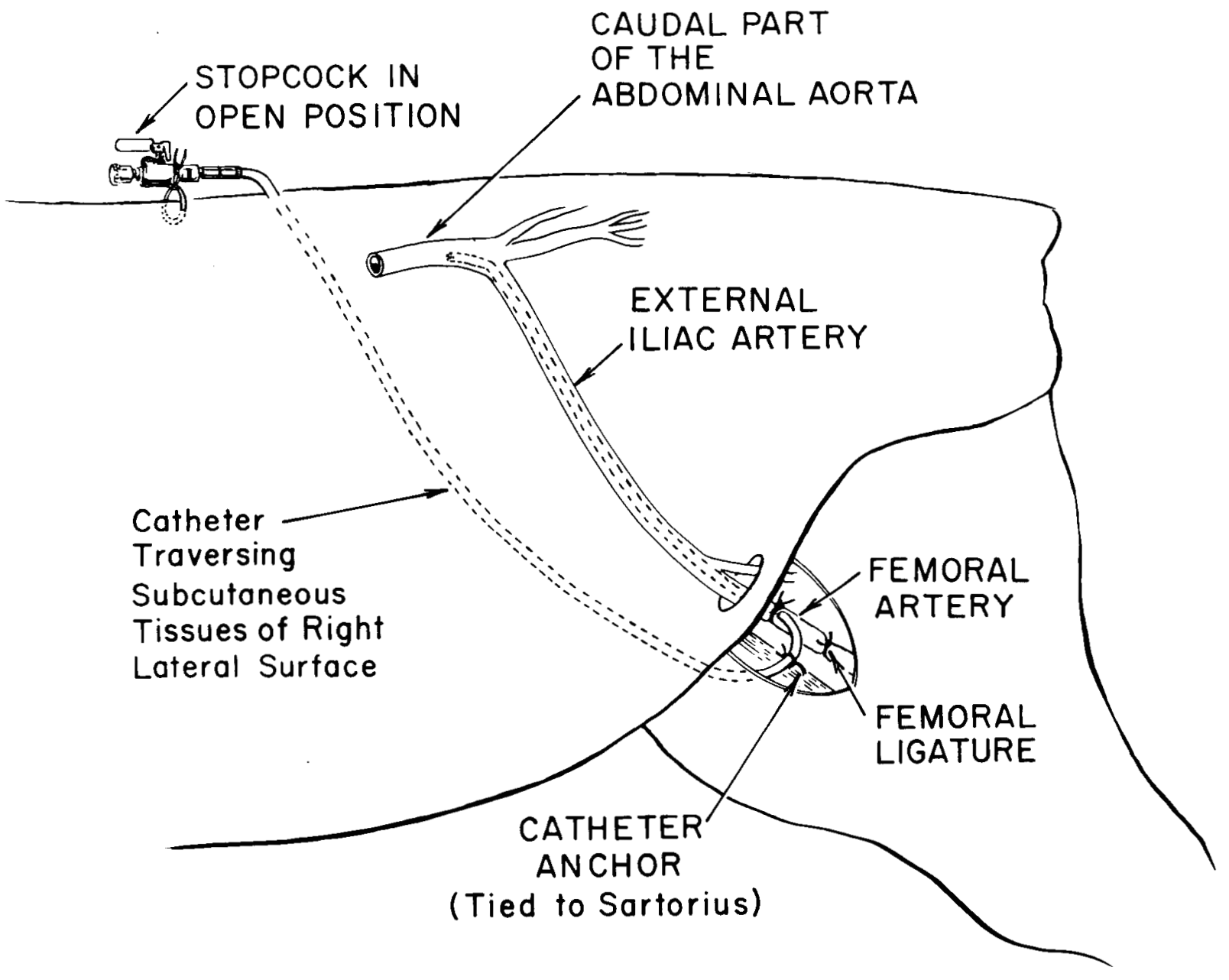

Figure 2. Cannulation of femoral artery for repeated sampling of arterial blood in unanesthetized sheep. 19 
electrodes were calibrated immediately before and after each analysis. All calibration gas mixtures were analyzed by the micro Scholander technique. $^{22}$

\section{Expired Gases}

During the blood sampling process, inspired and expired carbon dioxide and nitrogen concentrations were monitored continuously with a Beckman Spinco Model LB-1 $\mathrm{CO}_{2}$ Analyzer with linearizer and a Med Science Electronics Model 305 AR nitrogen analyzer, respectively. The respiratory traces from these instruments were recorded with a Honeywell Model 1508 Visicorder. The animals were connected directly to the breathe-through sample cell of the $\mathrm{CO}_{2}$ analyzer by means of a latex mask (Fig. 3). A low dead space, Hans-Rudolph type, two-way breathing valve was connected by a short piece of tygon tubing to the back of the breathethrough sample cell. The mask and instrument dead space was approximately $90 \mathrm{cc}$. The mixed expired gases were collected in 30-liter Douglas bags and analyzed for $\mathrm{O}_{2}$ and $\mathrm{CO}_{2}$ concentration by both the micro Scholander technique and the blood gas electrodes described above. Expired gas volumes were measured with a dry gas meter and corrected to the body temperature and pressure saturated with water vapor (BTPS). Oxygen consumption $\left(\stackrel{\circ}{\mathrm{V}}_{\mathrm{O}_{2}}\right)$ and $\mathrm{CO}_{2}$ elimination $\left(\stackrel{\circ}{\mathrm{V}}_{\mathrm{CO}_{2}}\right)$ were corrected to standard temperature and pressure, dry (STPD).

\section{CALCULATIONS}

All calculations were performed on a Burroughs B5500 electronic computer.

\section{Alveolar Gas Tensions and Pulmonary Ventilation}

The $\mathrm{P}_{\mathrm{ACO}_{2}}$ values were calculated from the mean end-tidal (E.T.) $\mathrm{CO}_{2}$ concentrations which were recorded during the blood sampling with the animals breathing either room air or oxygen. The procedure for cal- 


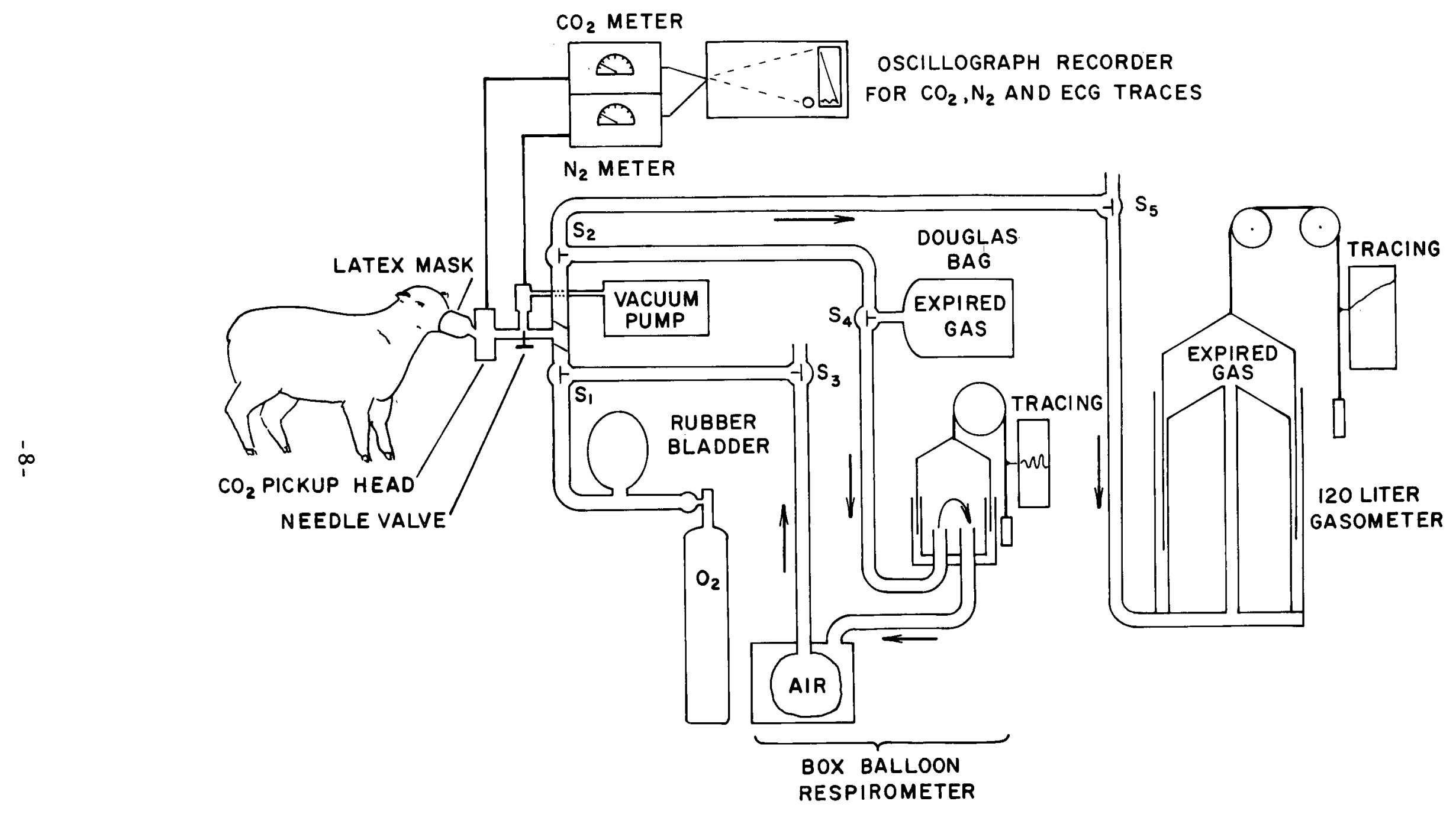

Figure 3. Schematic of equipment for conducting pulmonary function tests on unanesthetized sheep. 
culating the alveolar gas tension, alveolar ventilation, and percent ineffective alveolar ventilation (alveolar dead space) were as described in Reference 23 and were corrected to the species body temperature $\left(39^{\circ} \mathrm{C}\right)$.

In the room-air tests, the volume of inspired gas $\left(\stackrel{\circ}{V}_{I}\right)$ was calculated from the measured volume of expired gas $\left(\mathrm{V}_{E}\right)$ and corrected to BTPS. 23

Venous-Arterial Shunt

An oxygen method was used to measure venous-to-arterial shunt as a fraction of the cardiac output. ${ }^{24}$ For animals breathing pure oxygen with the hemoglobin fully saturated, the following equation was used:

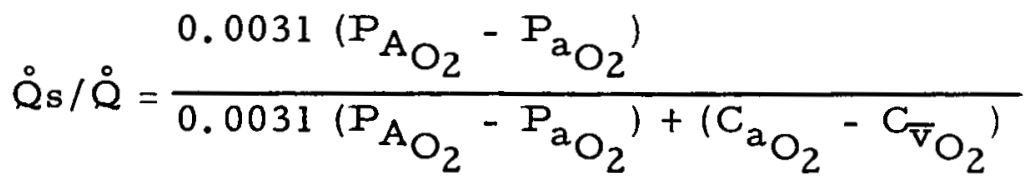

where $\grave{Q}_{s} / \stackrel{Q}{Q}$ = the venous-arterial shunt as a fraction of the cardiac output; ${ }^{\mathrm{P}_{\mathrm{O}_{2}}}-\mathrm{P}_{\mathrm{a}_{2}}=$ the difference in oxygen tension between the alveolar gas and the arterial blood; 0.0031 = the oxygen solubility factor for plasma; and $\mathrm{C}_{\mathrm{a}_{\mathrm{O}}}-\mathrm{C}_{\overline{\mathrm{v}}_{\mathrm{O}}}=$ the arteriovenous oxygen content difference $(\mathrm{a}-\overline{\mathrm{v}}) \mathrm{O}_{2}$. The $(a-\bar{v}) \mathrm{O}_{2}$ difference remains fairly constant at resting levels of $\mathrm{O}_{2}$ consumption and cardiac output. An average value for $(a-\bar{v})_{O_{2}}$ difference in these animals was obtained by cardiac catheterization of five sheep. The oxygen content of arterial blood and mixed venous blood was measured by the Van Slyke method. The following means and ranges of the $(a-\bar{v}) O_{2}$ differences were obtained: 


\begin{tabular}{|c|c|c|c|}
\hline & Number of & $(a-\bar{v})_{O}$ & ifference \\
\hline & Determinations & Mean & Range \\
\hline Nonanesthetized Anima & & & \\
\hline Breathing Room Air & 5 & 4.2 & $3.0-6.0$ \\
\hline Nonanesthetized Anima & & & \\
\hline Breathing $\mathrm{O}_{2}$ & 2 & 5.5 & $4.1-6.9$ \\
\hline Anesthetized Animals & & & \\
\hline Breathing Room Air & 2 & 5.3 & $4.3-6.3$ \\
\hline & $\mathrm{Me}$ & 5.0 & \\
\hline
\end{tabular}

The overall mean value of 5.0 was used for both sheep and dogs in all calculations involving $(\mathrm{a}-\overline{\mathrm{v}}) \mathrm{O}_{2}$ difference.

For animals with $\mathrm{Pa}_{\mathrm{O}_{2}}$ less than $120 \mathrm{~mm} \mathrm{Hg}$, the hemoglobin would not be 100 percent saturated and, therefore, equation (1) would not apply. In these cases, the percent saturation of the blood $\left(\mathrm{S}_{\mathrm{O}_{2}}\right)$ was derived from the measured $\mathrm{PaO}_{2}$ by using oxygen dissociation curves 25 and equation (1) modified as follows:

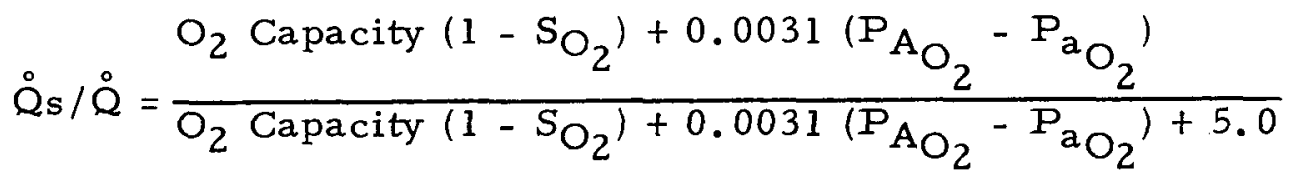

The mean and standard deviation of 12 pre-exposure determinations of $\mathrm{O}_{2}$ capacity in sheep was $14.5 \pm 1.71 \mathrm{ml} \mathrm{O} / 100 \mathrm{ml}$ blood. For sheep in which the $\mathrm{O}_{2}$ capacity was not measured, this pre-exposure mean was used for calculation of $\stackrel{\circ}{\mathrm{s} / Q} \dot{\mathrm{Q}}$. For dogs, the value used was $20.0 \mathrm{ml} \mathrm{O} /$ $100 \mathrm{ml}$ blood.

\section{Breakdown of Causes of Alveolar-Arterial Oxygen Differences}

$(A-a) \mathrm{O}_{2}$ for Animals Breathing Air

The estimation of that portion of the $(\mathrm{A}-\mathrm{a}) \mathrm{O}_{2}$ gradient due to venous admixture alone was based upon the following equation, the derivation of 
which has been previously described: 26

$$
\mathrm{C}_{\mathrm{a}^{\prime} \mathrm{O}_{2}}=\mathrm{C}_{\mathrm{CO}_{2}}-\stackrel{\mathrm{Q}_{\mathrm{s}} / \mathrm{Q}}{\frac{5.0}{1-Q_{\mathrm{s}} / \mathrm{Q}}}
$$

where $C_{a^{\prime} O_{2}}=$ virtual $C_{a_{O_{2}}}$ due to shunt and $5.0=(a-\bar{v})_{O_{2}}$ difference.

The procedure was to obtain $\mathrm{S}_{\mathrm{C}_{2}}$ from the $\mathrm{O}_{2}$ dissociation curve for the $\mathrm{pH}$ and $\mathrm{PA}_{\mathrm{O}_{2}}$ of the subject and then calculate $\mathrm{C}_{\mathrm{C}_{2}}$ from:

$$
\mathrm{C}_{\mathrm{C}_{\mathrm{O}_{2}}}=\mathrm{S}_{\mathrm{C}_{2}}\left(\mathrm{O}_{2} \text { capacity }\right)+0.0031 \mathrm{P}_{\mathrm{A}_{2}}
$$

$\mathrm{C}_{\mathrm{a}^{\prime} \mathrm{O}_{2}}$ was then calculated from (1) using $\mathrm{C}_{\mathrm{CO}_{2}}$ and $\mathrm{Q}_{\mathrm{s}} / \stackrel{\mathrm{Q}}{\mathrm{Q}}$ as inputs. $\mathrm{S}_{\mathrm{a}^{\prime} \mathrm{O}_{2}}$ was obtained from $\mathrm{C}_{\mathrm{a}^{\prime} \mathrm{O}_{2}}$ and the $\mathrm{O}_{2}$ capacity. $\mathrm{P}_{2}{ }^{\prime} \mathrm{O}_{2}$ was then read from the $\mathrm{O}_{2}$ dissociation curve for $\mathrm{S}_{\mathrm{a}} \mathrm{O}_{2}$ and the $\mathrm{pH}$.

$\mathrm{P}_{\mathrm{AO}_{2}}-\mathrm{P}_{\mathrm{a}^{\prime} \mathrm{O}_{2}}$ gave the part of the alveolar-arterial oxygen tension difference due solely to the venous-arterial shunt. The remainder of the $(A-a) \mathrm{O}_{2}$ difference was due to impairment of diffusion capacity or aberrations in the $\stackrel{\circ}{\mathrm{V}}_{\mathrm{A}} / \stackrel{\circ}{\mathrm{Q}}$ ratio. 26,27

\section{RESULTS}

The results of the study are illustrated in Figures 4 through 7 and presented in Tables 1 through 7 in the Appendix. The most significant findings are reviewed in the following sections.

\section{Venous-Arterial Shunt}

\section{A. Pre-Exposure Tests}

Totals of 43 pre-shot determinations of the percent venous-arterial shunt (Q̊s/Q̊) in 25 unanesthetized sheep and 24 determinations of Q̊s/Q̊ in 19 anesthetized sheep were conducted. The mean values, standard deviations, and ranges were $7.2 \pm 1.89$ percent (3.5-10.6), and $7.8 \pm 2.38$ percent (3.5-11.2) for unanesthetized and anesthetized sheep, respectively. In 


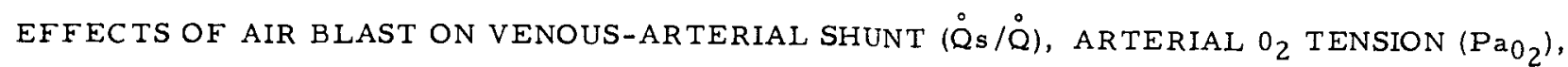
AND ALVEOLAR-ARTERIAL $0_{2}$ GRADIENT $(A-a)_{0_{2}}$, IN SHEEP AND DOGS

\begin{tabular}{|c|c|c|c|c|c|c|c|c|c|c|c|c|}
\hline $\begin{array}{l}\text { Animal } \\
\text { Number } \\
\end{array}$ & $\begin{array}{l}\text { Lung Weight, } \\
\text { Per Cent of } \\
\text { Body Weight }\end{array}$ & $\begin{array}{c}\text { Lung } \\
\text { Hemorrhage }\end{array}$ & $\begin{array}{c}\text { Reflected } \\
\text { Pressure, } \\
\text { psi }\end{array}$ & & $\begin{array}{l}\text { Q. } \\
30\end{array}$ & $\%$ & $\begin{array}{r}\mathrm{PaO}_{2} \\
40 \\
\end{array}$ & $\mathrm{~nm}$ & $g$. & $\begin{array}{c}(A-a)_{0} \\
20\end{array}$ & 40 & $\begin{array}{l}\mathrm{Hg} \\
60 \\
\end{array}$ \\
\hline \\
\hline $381^{a}$ & 0.96 & None & 10 & & & & & & & & & \\
\hline $401^{a}$ & 0.89 & Petechial & 17 & & & & & & & & & \\
\hline $372^{a}$ & 0.92 & Petechial & 21 & & & & & & & & & \\
\hline $386^{a}$ & 1.14 & Small Isolated & 21 & & & & & & & & & \\
\hline $366^{a}$ & 0.92 & Small Isolated & $32^{b}$ & & & & & & & & & \\
\hline 570 & & & 33 & & & & & & & & & \\
\hline 715 & & & 34 & & & & & & & & & \\
\hline 646 & & & 34 & & & & & & & & $p$ & \\
\hline 811 & & & 35 & & & & & & & & & \\
\hline 794 & & & 38 & & & & & & & & & \\
\hline 000 & & & 40 & & & & & & & & & \\
\hline 771 & & & 40 & & & & & & & & & \\
\hline 750 & & & 40 & & & & & & & & $\mathbf{P}$ & \\
\hline 187 & 1.21 & Confluent & 41 & & & & & & & & & \\
\hline 172 & 1.17 & Confluent & 42 & & & & & & & & د & \\
\hline $384^{a}$ & 1.31 & Confluent & $74^{b}$ & & & & & & & & & \\
\hline 821 & & & 42 & & & & & & & & 月 & \\
\hline 181 & 2.33 & Entire Lobes & 43 & & & & & & & & ? & \\
\hline $487^{a}$ & 2. 54 & Entire Lobes & $122^{b}$ & & & & & & & & & \\
\hline 825 & & & 45 & & & & & & & 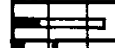 & & \\
\hline $407^{a}$ & 2.51 & Entire Lobes & 48 & & & & $E$ & & & & & \\
\hline & & Control $n$ & & & & & & & & & & \\
\hline \multicolumn{12}{|l|}{ Beagles } & \\
\hline$D-19$ & 1.47 & Confluent & 37 & & & & & & & & & \\
\hline$D-43$ & 1.12 & Confluent & 40 & & & & & & & & & \\
\hline$D-22$ & 3.85 & Entire Lobes & 39 & & & & & & & & & \\
\hline $\mathrm{D}-44$ & 2.65 & Entire Lobes & 39 & & & & & & & & & \\
\hline \multirow[t]{2}{*}{$D-53^{a}$} & 3.77 & Entire Lobes & 42 & & & & & & & & & \\
\hline & & Control r & & & & & & & & & & \\
\hline
\end{tabular}

$a=$ Anesthetized

Pre-exposure

Note: Shaded part of $(A-a) 0_{2}$ bar is

$b=$ Exposed to 64-lb charge of TNT

Post-exposure

portion due to shunt only.

Figure 4. 
EFFECTS OF AIR BLAST ON VENOUS ARTERIAL SHUNT $(\stackrel{Q}{\mathrm{Q}} / \stackrel{\circ}{\mathrm{Q}})$, ARTERIAL $0_{2}$ TENSION $\left(\mathrm{P}_{\mathrm{a}_{2}}\right)$, AND ALVEOLAR-ARTERIAL $0_{2}$ GRADIENT (A-a) $0_{2}$, IN SHEEP AND DOGS

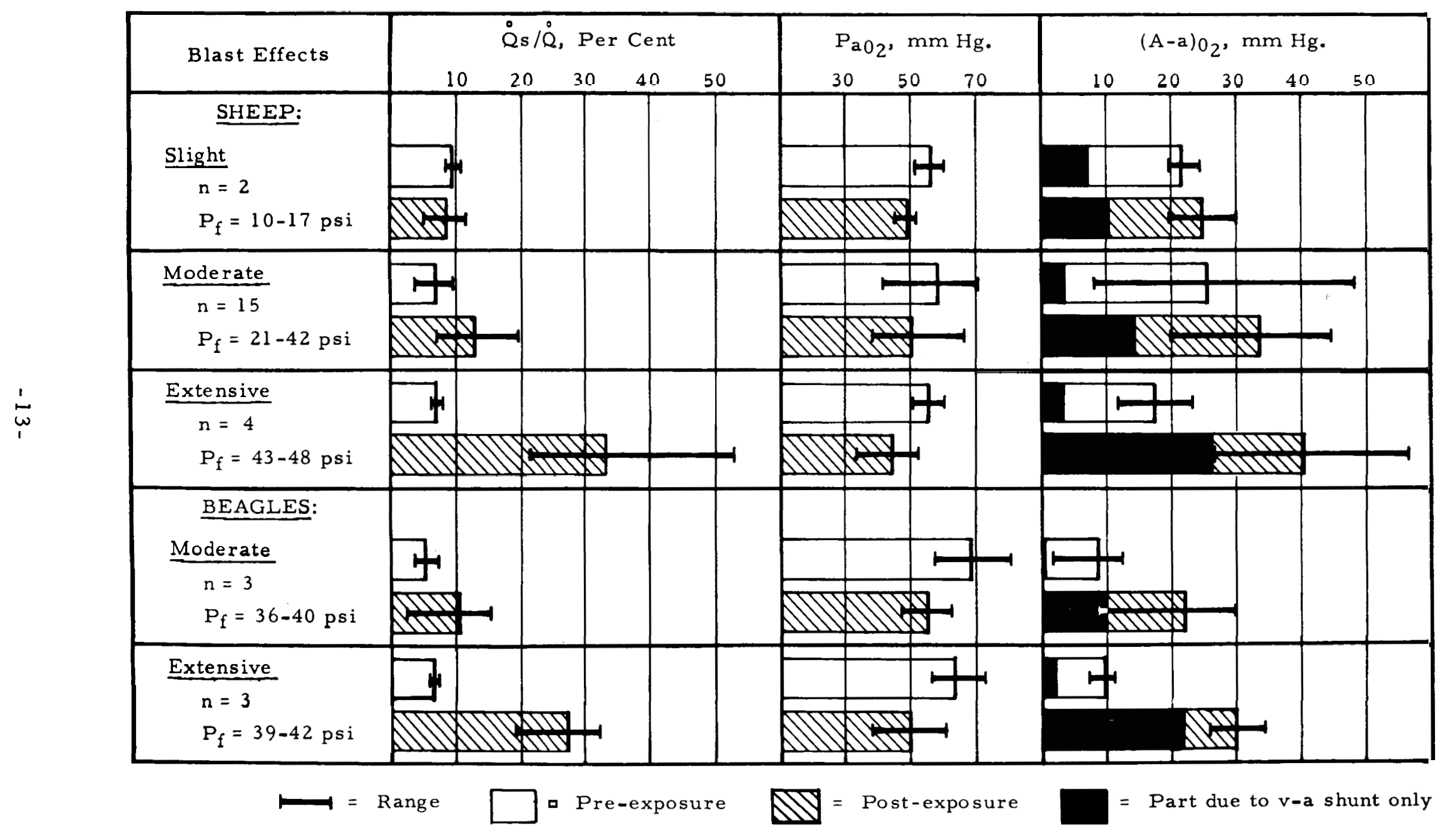

Figure 5. 
EFFECTS OF AIR BLAST ON RESPIRATORY RATE, C $0_{2}$ TENSION $\left(\mathrm{PaC}_{2}\right)$,

AND $\mathrm{pH}$ OF THE ARTERIAL BLOOD FOR ANIMALS BREATHING AIR

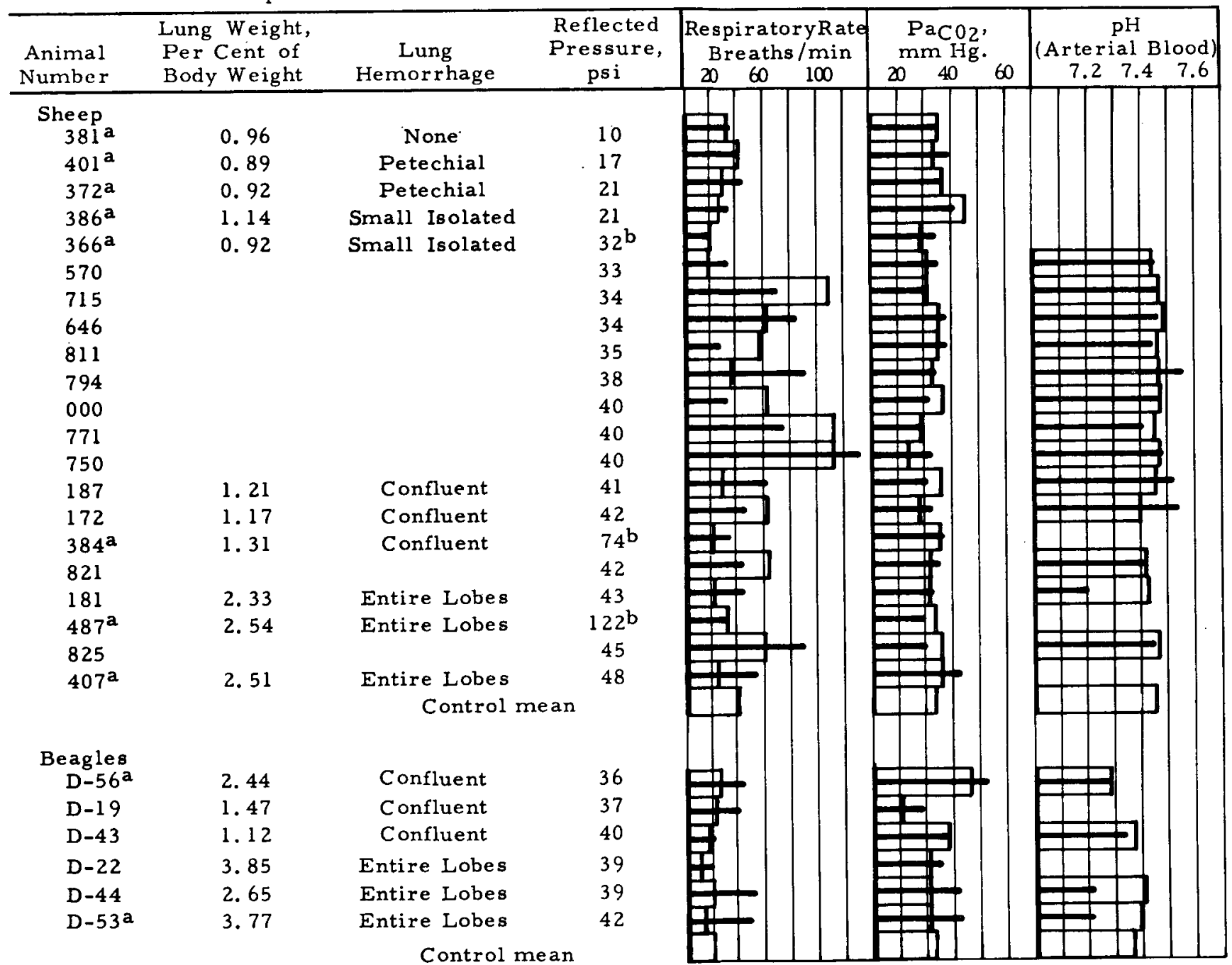

$a=$ Anesthetized

$b=$ Exposed to $64-1 b$ charge of TNT

Pre-exposure

Post-exposure

Figure 6. 
EFFECTS OF AIR BLAST ON VENTILATION $\left(\stackrel{\circ}{\mathrm{V}}_{\mathrm{I}}\right), \mathrm{CO}_{2}$ GRADIENT $\left[\left(\mathrm{a}-\mathrm{E} . \mathrm{T} . \mathrm{C}_{\mathrm{C}} \mathrm{C}_{2}\right]\right.$, AND INEFFECTIVE ALVEOLAR VENTILATION $\left[(a-E . T.) \mathrm{CO}_{2} / \mathrm{Pa} \mathrm{CO}_{2}\right]$ IN ANIMALS BREATHING AIR

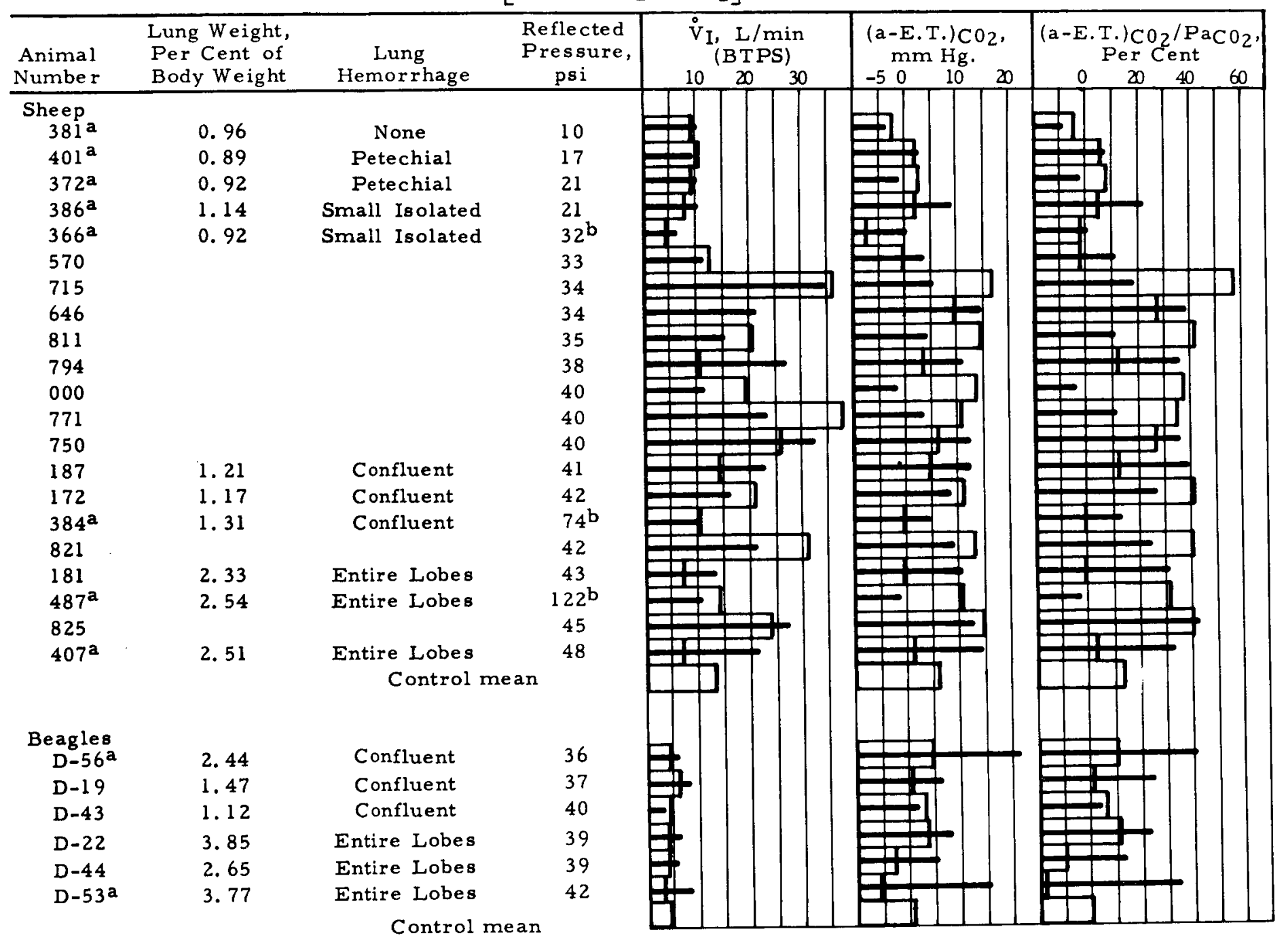

$a=$ Anesthetized

$b=$ Exposed to $64-1 b$ charge of TNT

$\square$ Pre-exposure

Post-exposure

Figure 7. 
10 of the above cases, tests with and without anesthesia were conducted on the same animals. The mean differences of the two tests for the 10 animals was 0.60 percent, which was not significant $(0.5>P>0.4)$. The results of tests both with and without anesthesia are summarized in the following sections.

The mean, standard deviation, and range for five pre-exposure

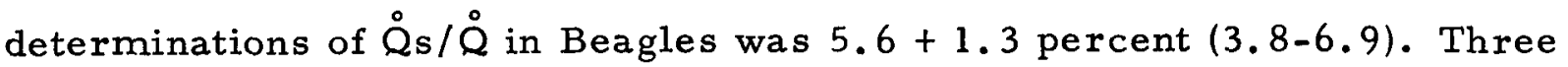
of these tests were conducted without anesthesia.

\section{B. Post-Exposure Tests}

Post-exposure tests were completed on 21 sheep and 6 Beagles. Eleven of the sheep and all of the dogs were sacrificed immediately upon completion of the pulmonary function tests to assess the extent of lungblast injury. The remainder of the animals were retained for studies of the chronic effects of air blast on pulmonary function, the results of which will be presented in a future report. Figure 4 lists the lung weights and extent of lung hemorrhage for the sacrificed animals, the reflected overpressure to which each animal was exposed, and illustrates the pre- and post-exposure Q̊s/Q̊ for each. The animals for which no lung weight data are presented were retained for follow-up studies of the blast-injury recovery pattern. Also shown in Figure 4 are the $\mathrm{PaO}_{2}$ and the alveolararterial $\mathrm{O}_{2}$ differences for animals breathing air. The control mean values presented in this and subsequent figures are for all pre-exposure tests. The figure indicates that with but two exceptions (sheep No. 811 and Beagle No. D-56) all animals exposed to "long"-duration reflected pressures in the range of 20 to $40 \mathrm{psi}$ exhibited variable increases in the post-exposure Q̊s/Q̊. The two sheep exposed to reflected pressures of 10 and 17 psi did not exhibit increased venous-arterial shunt. At the higher pressure levels, increases in the $\grave{Q}_{s} / \grave{Q}$ were generally correlated with increasing levels of blast lung injury as indicated by the lung weight data and the extent of 
lung hemorrhage observed at autopsy. This correlation was more evident in the dogs than in the sheep.

Concurrent with increases in $\grave{Q}_{s} / \stackrel{Q}{Q}$, there were usually decreases in the arterial oxygen tensions $\left(\mathrm{P}_{\mathrm{aO}_{2}}\right)$ and increases in the alveolar-arterial oxygen gradients $(\mathrm{A}-\mathrm{a}) \mathrm{O}_{2}$ for animals breathing air (Fig. 4). As indicated by the shaded portions of the $(A-a) \mathrm{O}_{2}$ bars in Figure 4, most of the post-blast increases in $(\mathrm{A}-\mathrm{a}) \mathrm{O}_{2}$ in the dogs were due to a $\mathrm{v}$-a shunt alone. For example, the mean post-exposure increase in the $(\mathrm{A}-\mathrm{a}) \mathrm{O}_{2}$ gradient in the six Beagles was $16.6 \mathrm{~mm} \mathrm{Hg}$, of which $14.2 \mathrm{~mm} \mathrm{Hg}$ were due to shunt and $2.4 \mathrm{~mm} \mathrm{Hg}$ to the other two factors that affect the $(\mathrm{A}-\mathrm{a}) \mathrm{O}_{2}$ gradient; namely, the diffusion capacity and aberrations in the $\stackrel{\circ}{\mathrm{A}}_{\mathrm{A}} / \stackrel{\mathrm{Q}}{ }$ ratio. 26,27 The portion of the $(\mathrm{A}-\mathrm{a}) \mathrm{O}_{2}$ gradient due to factors other than the shunt (represented by the clear portions of the bars in Fig. 4) changed very little after the blast. Although there were inconsistencies in these relationships in the sheep data, the pattern described above is clearly indicated by the mean values obtained when the animals were grouped according to level-of-blast injury as shown in Figure 5. The sheep were divided into blast-response groups designated as slight, moderate, or extensive on the basis of the degree of lung hemorrhage and/or overpres sure. The dogs were similarly divided into two groups exhibiting moderate or extensive injuries. Figure 5 lists the number of animals, range of the reflected pressure $\left(P_{f}\right)$, and shows the mean and range of the pre- and post-exposure $\stackrel{\circ}{\mathrm{Q}} / \stackrel{\mathrm{Q}}{\mathrm{Q}}, \mathrm{P}_{\mathrm{a}_{2}}$, and $(\mathrm{A}-\mathrm{a}) \mathrm{O}_{2}$ for each group. The figure illustrates that, for sheep with no or only slight injuries, the mean, post-exposure, venous-arterial shunt was about the same as the pre-exposure value, whereas the arterial oxygen tension was slightly reduced and the $(A-a) \mathrm{O}_{2}$ gradient was slightly increased. For animals with moderate injuries, the mean post-exposure $Q_{s} / \dot{Q}$ was increased beyond the pre-exposure range, the $\mathrm{P}_{\mathrm{O}_{2}}$ was slightly reduced, and the $(\mathrm{A}-\mathrm{a}) \mathrm{O}_{2}$ was moderately increased 
with most of the increase attributable to the change in $Q_{s} / \grave{Q}$. For animals with extensive injuries, there was a very marked increase in the mean

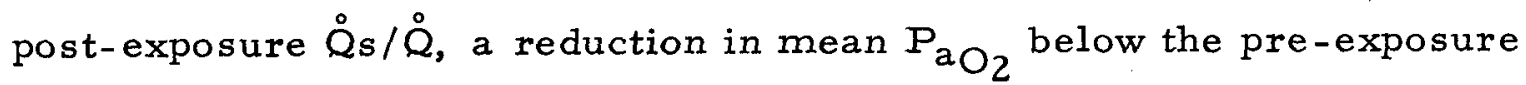
range and a marked increase in $(\mathrm{A}-\mathrm{a}) \mathrm{O}_{2}$, most of which was due solely to the increased venous-arterial shunt.

Respiratory Rate, $\mathrm{CO}_{2}$ Tension, and $\mathrm{pH}$ of the Arterial Blood

The $\mathrm{P}_{\mathrm{aCO}_{2}}, \mathrm{pH}$, and respiratory rate data are summarized in Figure 6. In most cases, the post-exposure $\mathrm{PaCO}_{2}$ values were within the normal range. There were slight increases in the post-exposure $\mathrm{P}_{\mathrm{aCO}_{2}}$ values of all dogs except $\mathrm{D}-43$, even though they exhibited increased respiratory rates. Dog D-56 had a slight pre-exposure respiratory acidosis $\left(\mathrm{P}_{\mathrm{a}_{2}}=47.0, \mathrm{pH}=7.29\right)$ that increased after air-blast exposure $\left(\mathrm{P}_{\mathrm{a}_{\mathrm{CO}}}=52.0, \mathrm{pH}=7.28\right)$. Sheep 181 showed metabolic acidosis which was only partially compensated by an increased respiratory rate $\left(\mathrm{P}_{\mathrm{a}_{\mathrm{CO}}}=33.0, \mathrm{pH}=7.20\right)$. Two of the most severely injured dogs had metabolic acidosis that was uncompensated by respiration even though their post-exposure respiratory rates were more than doubled $\left(\mathrm{P}_{\mathrm{aCO}_{2}}=\right.$ 42.0, $\mathrm{pH}=7.22$ and $\mathrm{P}_{\mathrm{aCO}_{2}}=43.0 . \mathrm{nH}=7.23$ for dogs $\mathrm{D}-44$ and $\mathrm{D}-53$, respectively).

Minute Volume, $\mathrm{CO}_{2}$ Gradient, and Ineffective Alveolar Ventilation

The data in Figure 7 shows that the arterial, end-tidal, $\mathrm{CO}_{2}$ difference (a-E.T. $\mathrm{CO}_{2}$, and hence the percent ineffective alveolar ventilation, was generally correlated with the minute volumes in tests both with and without anesthesia. In addition to this, most of the dogs, and especially the two tested under anesthesia (D-56 and D-53), exhibited very marked post-exposure increases in the (a-E.T. $\mathrm{CO}_{2}$ gradient which was attributable to increased alveolar dead space ventilation. In the sheep, changes in these parameters were variable and inconsistent. 
Oxygen Consumption, Carbon Dioxide Elimination, and Respiratory

Exchange Ratio

According to the data in Table 5 of the Appendix, the effects of air blast on oxygen consumption $\left(\stackrel{\circ}{\mathrm{V}}_{\mathrm{O}_{2}}\right)$, carbon dioxide elimination $\left(\stackrel{\circ}{\mathrm{V}}_{\mathrm{CO}_{2}}\right)$ and respiratory exchange ratio $(R)$ were generally slight and inconsistent. Two of the more severely injured dogs (D-53 and D-44) exhibited slight decreases in both $\stackrel{\circ}{\mathrm{V}}_{\mathrm{O}_{2}}$ and $\stackrel{\circ}{\mathrm{V}}_{\mathrm{CO}_{2}}$ even though their pulmonary ventilation, following blast exposure, was increased (c.f., Tables 5 and 6). In one of the sheep (825) which was exposed to a reflected pressure of 45 psi and showed only a moderate increase in Q̊s/Q (Fig. 4), there was a great increase in $\stackrel{\circ}{\mathrm{V}}_{\mathrm{O}_{2}}$ and a reduction in $\stackrel{\circ}{\mathrm{V}}_{\mathrm{CO}_{2}}$ so that $\mathrm{R}$ was reduced to 0.33 . Consistent with the increased oxygen consumption was an elevation in the heart rate of this animal from a pre-shot value of 88 to 179 beats per minute after exposure.

\section{DISCUSSION}

The immediate post-exposure increase in the venous-arterial shunt, which was usually related to the extent of blast lung injury in the se animals, indicates that there is a continuation of blood flow through blast-injured, nonventilated regions of the lungs resulting in an increase in the venous admixture. The increased venous admixture represents the composite effect of blood flow through regions of the lungs with atelectasis, intra-alveolar hemorrhage, airways blocked with hemorrhage, edema, or disruption of tissues by blast injury. This usually leads to hypoxia which persists even with increased ventilation.

Part of the increase in the venous-arterial shunt could also be due to pulmonary hypertension. Chronic pulmonary hypertension, due to causes other than trauma, has been reported to cause an elevation in the venous admixture attributed to an increase in the blood flow through anatomical arteriovenous shunts in the lungs. 28 That pulmonary hypertension 
occurs in blast injury is indicated by the frequent occurrence of marked dilation of the right heart. ${ }^{4}$

It should be emphasized that in those animals that were exposed to "long"-duration overpressures at levels near or above the threshold for lethality ( $\geq 43 \mathrm{psi}$ ), the lung injury was usually so severe that the $v-a$ shunt exceeded 30 percent of the cardiac output and, in such cases, hypoxia was not entirely alleviated even with the subject breathing pure oxygen. One might conclude, therefore, that most of the survivors from exposure to blast overpressure at or above the lethal threshold level would probably be unable to perform tasks requiring exercise because of the lung injuries sustained. Furthermore, exercise, in such cases, may result in increased morbidity and mortality because of such attendant effects as: (1) increase in respiratory excursions of the lung with the possible consequence of further injection of air emboli into the circulation; (2) increase in cardiac output resulting in persistent pulmonary bleeding leading to a progressive increase in the venous-arterial shunt and reduction of $\mathrm{P}_{\mathrm{OO}_{2}}$; and (3) progressive metabolic acidosis as a result of hypoxia and increasing anaerobic metabolism.

The fact that animals with lung injuries as slight as petechial hemorrhages showed an increase in the venous admixture indicates that the threshold pressures for lung injury from the standpoint of gross pathology ( 20 psi for overpressures of "long" duration) may also be regarded as the threshold for impairment of pulmonary function. The main effect of slight lung injuries, however, would be a reduction in the pulmonary reserve which would cause respiratory distress only under conditions of severe exercise.

The pre-exposure mean $\mathrm{CO}_{2}$ gradient for six dogs was $0.3 \mathrm{~mm} \mathrm{Hg}$ with a range of -6 to $5 \mathrm{~mm} \mathrm{Hg}$ (Table 3, Appendix B). After blast exposure, the mean value increased to $10 \mathrm{~mm} \mathrm{Hg}$ with a range of 2 to $22 \mathrm{~mm} \mathrm{Hg}$. 
The $\mathrm{CO}_{2}$ gradient reflects the $\stackrel{\circ}{\mathrm{A}}_{\mathrm{A}} / \stackrel{\circ}{\mathrm{Q}}$ ratio. ${ }^{23}$ Negative $\mathrm{CO}_{2}$ gradients occur during anesthesia or under conditions in which the ratio of the heart rate to the respiratory rate is high, as during heavy exercise. 29 Hence, the increases in the $\mathrm{CO}_{2}$ gradients occurring in these dogs following airblast exposure may have been partly the result of an increased respiratory rate relative to the heart rate, but may also have been due to lung-blast injury resulting in disruption of pulmonary cirćlation to alveoli in which ventilation was still occurring. 23 In any event, the result was an increase in the percent of the alveolar ventilation which was ineffective for gas exchange (Fig. 7). In most cases, these same effects were evident in the sheep data: the greatest post-exposure increases in the $\mathrm{CO}_{2}$ gradient occurred in those animals with the highest venous-arterial shunt (c.f., Figs. 4 and 7). However, the changes in $\mathrm{CO}_{2}$ gradients observed in these sheep were not as great as anticipated on the basis of results of earlier studies in which this parameter was measured on anesthetized sheep following exposure to explosive charges. In the latter case, 11 of 14 animals exhibited post-exposure $\mathrm{CO}_{2}$ gradients above the range of the pre-shot controls with values up to $29 \mathrm{~mm} \mathrm{Hg}$ for animals with severe lung damage. 30

The marked post-exposure reductions in the blood $\mathrm{pH}(\mathrm{Fig}$. 6) seen in two of the most severely injured dogs (D-44 and D-53) and one of the more severely injured sheep (181), coupled with $\mathrm{CO}_{2}$ tensions in the normal or below normal range, indicate the occurrence of metabolic acidosis; probably resulting from a build-up of lactic acid due to hypoxia. Thus, it is the nature of severe lung-blast injury that increased ventilation may compensate or even overcompensate for a build-up in $\mathrm{CO}_{2}$ in the blood but cannot fully compensate for the increased metabolic acidosis which results from hypoxia caused primarily by increased venous-arterial shunt.

The question arises as to the time required for recovery from lungblast injury and the ability of the pulmonary system to compensate for such 
injuries. The material presented in this report has been limited to the immediate effects of lung-blast injury on pulmonary function. The timerecovery patterns of the respiratory system from such injuries and the results of studies of the incidence of chronic, irreversible, or residual effects will be presented in a future report. 
1. Benzinger, T., "Physiological Effects of Blast in Air and Water," Chap. XIV-B, German Aviation Medicine, World War II, II: 1225 1259, U.S. Government Printing Office, Washington, D. C., 1950.

2. Zuckerman, S., "Experimental Study of Blast Injuries to the Lungs," Lancet, $\underline{2}: 219-238,1940$.

3. Clemedson, C. -J., "An Experimental Study on Air Blast Injuries," Acta Physiol. Scand., 18, Supplement 61: 1-200, 1949.

4. Clemedson, C.-J., "Blast Injury," Physiol. Rev., 36: 336-354, 1956.

5. White, C. S. and D. R. Richmond, "Blast Biology," USAEC Technical Report, TID-5764, Office of Technical Services, Department of Commerce, Washington, D. C., September 18, 1959. Also Chap. 63 in Clinical Cardiopulmonary Physiology, Ross C. Kory and Burgess L. Gordon (editors), Grune and Stratton, Inc., New York, 1960.

6. Rōssle, R., "Pathology of Blast Effects," Chap. XIV-C, German Aviation Medicine, World War II, II: 1260-1273, U. S. Government Printing Office, Washington, D. C., 1950.

7. Richmond, D. R., E. G. Damon, E. R. Fletcher, I. G. Bowen, and C. S. White, "The Relationship Between Selected Blast-Wave Parameters and the Response of Mammals Exposed to Air Blast," Technical Progress Report No. DASA 1860, Defense Atomic Support Agency, Department of Defense, Washington, D. C., November 1966. Also in Ann. N.Y. Acad. Sci. 152: 103-121, 1968.

8. Chiffelle, T. L., "Pathology of Direct Air-Blast Injury," Technical Progress Report No. DASA 1778, Defense Atomic Support Agency, Department of Defense, Washington, D. C., April 1966.

9. Hooker, D. R., "Physiological Effects of Air Concussion," Amer. J. Physiol., 67: 219-274, 1924.

10. Krohn, P. L., D. Whitteridge, and S. Zuckerman, "Physiological Effects of Blast," Lancet, 1: 252-258, February 28, 1942. 
11. Clemedson, C. -J., "Respiration and Pulmonary Gas Exchange in Blast Injury," J. Appl. Physiol. 6: 213-220, 1953.

12. Clemedson, C.-J., L. Elstorp, H. Pettersson, and A. B. Sundquist, "Changes of Elastic Properties of Lungs of Rabbits in Air Blast Injury, "Aerospace Med. 37: 1125-1130, 1966.

13. Damon, E. G., C. S. Gaylord, W. Hicks, J. T. Yelverton, D. R. Richmond, and C. S. White, "The Effects of Ambient Pressure on Tolerance of Mammals to Air Blast," Technical Progress Report No. DASA 1852, Defense Atomic Support Agency, Department of Defense, Washington, D. C., August 1966. Also in Aerospace Med. 39: 1039-1047, 1968.

14. Richmond, D. R., C. S. Gaylord, and E. G. Damon, "DASA-AECLovelace Foundation Blast-Simulation Facility," Technical Progress Report No. DASA 1853, Defense Atomic Support Agency, Department of Defense, Washington, D. C., August 1966.

15. Damon, E. G., C. S. Gaylord, J. T. Yelverton, and D. R. Richmond, "The Tolerance of Cattle to 'Long'-Duration Reflected Pressures in a Shock Tube, "Technical Progress Report No. DASA 1855, Defense Atomic Support Agency, Department of Defense, Washington, D. C., August 1966.

16. Richmond, D. R., V. R. Clare, V. C. Goldizen, D. E. Pratt, R. T. Sanchez, and C. S. White, "Biological Effects of Overpressure. II. A Shock Tube Utilized to Produce Sharp-Rising Overpressures of 400 Milliseconds Duration and Its Employment in Biomedical Experiments," Technical Progress Report No. DASA 1246, Defense Atomic Support Agency, Department of Defense, Washington, D. C., April 7, 1961. Also in Aerospace Med. 32: $997-1008,1961$.

17. Hamilton, R. W., Jr., "Continuous Sampling of Arterial Blood of Unanesthetized Animals, "Technical Documentary Report No. SAMTDR-64-67, USAF School of Aerospace Medicine, Aerospace Medical Division (AFSC), Brooks Air Force Base, Texas, December 1964.

18. Wezler, K. and R. Thauer, "Umblutige Druckregistrierung am Tier mittels der Carotiss chlinge," Z. Ges. Exp. Med. 108: 377397,1940 . 
19. Yelverton, J. T., E. A. Henderson, and R. W. Dougherty, "A Chronically Implanted Arterial Catheter for Unanesthetized Animals, " Cornell Vet. 59: 466-472, July 1969.

20. Spector, W. S. (editor), Handbook of Biological Data, Technical Report No. WADC 56-273, Table 311, p. 343, Wright Air Development Center, Air Research and Development Command, U.S. Air Force, Wright-Patterson Air Force Base, Ohio, 1956.

21. Severinghaus, J. W., "Blood Gas Concentrations," Handbook of Physiology, Respiration, Section 3, Vol. II, Chap. 61, pp. 14751487, American Physiological Society, Washington, D. C., 1965.

22. Scholander, P. F., "Analyzer for Accurate Estimation of Respiatory Gases in One-Half Cubic Centimeter Samples, "J. Biol. Chem. 167: 235-259, 1947 .

23. Comroe, J. H., Jr., R. E. Forster II, A. B. DuBois, W. A. Briscoe, and E. Carlsen, The Lung., Clinical Physiology and Pulmonary Function Tests (2nd edition), Year Book Medical Publishers, Inc., Chicago, I1l., 1962.

24. Finley, T. N., C. Lenfant, P. Haab, J. Piiper, and H. Rahn, "Venous Admixture in the Pulmonary Circulation of Anesthetized Dogs, " J. Appl. Physiol. 15(3): 418-424, 1960.

25. Dittmer, D. S. and R. M. Grebe (editors), Handbook of Respiration, prepared under Direction of Committee on the Handbook of Biological Data, Division of Biology and Agriculture, National Academy of Sciences, National Research Council, W. B. Saunders Co., pp. $78-80,1958$.

26. Ayres, S. M., A. Criscitiello, and E. Grabovsky, "Components of Alveolar-Arterial $\mathrm{O}_{2}$ Difference in Normal Man, " J. Appl. Physiol. $\underline{19}(1): 43-47,1964$.

27. Rahn, H., and L. E. Farhi, "Ventilation, Perfusion, and Gas Exchange - the $\mathrm{V}_{\mathrm{A}} / \mathrm{Q}$ Concept, " Handbook of Physiology, Respiration, Section 3, Vol. I, Chap. 30, pp. 749-751, American Physiological Society, Washington, D. C., 1964.

28. Kentera, D., C. R. Wallace, W. F. Hamilton, and L. T. Ellison, "Venous Admixture in Dogs with Chronic Pulmonary Hypertension," J. Appl. Physiol. 20(5): 919-921, 1965. 
29. Wasserman, K., A. L. Van Kessel, and G. G. Burton, "Interaction of Physiological Mechanisms During Exercise," J. Appl. Physiol. 22(1): $71-85,1967$.

30. Damon, E. G.: Defense Atomic Support Agency Project, Lovelace Foundation for Medical Education and Research, Albuquerque, N. Mex., unpublished data. 


\section{APPENDIX A}

\section{ABBREVIATIONS AND SYMBOLS}

Wherever possible, the standa rdized symbols and abbreviations recommended in Federation Proc. 9:602-605, 1950, are used:

General Symbols:

$\stackrel{\circ}{\mathrm{X}}=$ dot above any symbol indicates a time dé rivative

$\overline{\mathrm{X}}$ = bar above any symbol indicates a mean value
Examples:

$\stackrel{\mathrm{V}}{=} \quad=$ volume of gas, $\mathrm{L} / \mathrm{min}$

$\overline{\mathrm{F}}_{\mathrm{A}_{\mathrm{CO}_{2}}=} \begin{aligned} & \text { mean fractional con- } \\ & \text { centration of carbon }\end{aligned}$ dioxide in alveolar gas

FOR GASES

\section{Primary Symbols}

(large capital letters):

$$
\begin{aligned}
& \mathrm{V} \text { = gas volume } \\
& \mathrm{P} \quad \text { = gas pressure } \\
& F \text { = fractional concentration in dry }
\end{aligned}
$$

Secondary Symbols

(capital letter subscripts):

$$
\text { I = inspired gas }
$$

$\mathrm{E} \quad=$ expired gas
Examples:

$$
\begin{aligned}
& \mathrm{v}_{\mathbf{T}} \quad=\text { tidal volume, } \mathrm{ml} \\
& \begin{aligned}
\mathrm{P}^{\mathrm{A}_{2}}= & \text { alveolar oxygen pres - } \\
& \text { sure, } \mathrm{mm} \mathrm{Hg}
\end{aligned} \\
& \mathrm{F}_{\mathrm{I}_{2}} \quad \begin{array}{l}
\text { fractional concentra- } \\
\text { tion of oxygen in in- }
\end{array}
\end{aligned}
$$

$$
\mathrm{R}=\stackrel{\circ}{\mathrm{V}}_{\mathrm{CO}_{2}} / \stackrel{\circ}{\mathrm{V}}_{\mathrm{O}_{2}}
$$

\section{Examples:}

$$
\begin{aligned}
& \mathrm{F}_{\mathrm{ICO}_{2}}= \begin{array}{l}
\text { fractional concentra- } \\
\text { tion of } \mathrm{CO}_{2} \text { in inspired } \\
\text { gas }
\end{array} \\
& \stackrel{\circ}{\mathrm{V}}_{\mathrm{E}_{\mathrm{BTPS}}=} \begin{array}{l}
\text { volume of expired gas, } \\
\text { body temperature and } \\
\text { pressure, saturated, } \\
\\
\mathrm{L} / \text { min }
\end{array}
\end{aligned}
$$



A = alveolar gas
$\stackrel{\circ}{\mathrm{V}}_{\mathrm{A}} \quad=$ alveolar ventilation,
E. T. = end-tidal gas
$\stackrel{\circ}{\mathrm{V}}_{\mathrm{D}} \quad=$ anatomic dead space ventilation, $\mathrm{L} / \mathrm{min}$
$\mathrm{P}_{\mathrm{B}} \quad$ = barometric pressure
$\begin{aligned}(\mathrm{a}-\mathrm{E} . \mathrm{T} .) \mathrm{CO}_{2}= & \text { arterial end- } \\ & \text { tidal } \mathrm{CO}_{2} \\ & \text { difference }\end{aligned}$
STPD = standard temperature and pressure, dry $10^{\circ} \mathrm{C}, 760 \mathrm{~mm}$ $\mathrm{Hg}$, dry)
BTPS = body temperature and pressure saturated with water vapor
ATPD = ambient temperature and pres- sure, dry
ATPS = ambient temperature and pres - sure saturated with water vapor

Prima ry Symbols

(large capital letters):

$$
\begin{aligned}
\mathrm{Q}= & \text { volume of blood } \\
\mathbf{C}= & \text { concentration of gas in } \\
& \text { blood phase } \\
\mathrm{S}= & \text { percent saturation of } \mathrm{Hb} \\
& \text { with } \mathrm{O}_{2} \\
\mathrm{Q}_{\mathrm{s}} / \mathrm{Q}= & \text { venous - arterial shunt }= \\
& \text { venous admixture with } \\
& \text { arterial blood in percent } \\
& \text { of cardiac output }
\end{aligned}
$$

\section{Secondary Symbols (small letters):}
a $=$ arterial blood
$\mathrm{v} \quad=$ venous blood
c = capillary blood

Examples:

$$
\begin{aligned}
& \stackrel{\mathrm{Q}}{=}=\text { cardiac output, } \mathrm{L} / \mathrm{min} \\
& \mathrm{C}_{\mathrm{a}_{2}}=\mathrm{ml} \mathrm{O}_{2} \text { in } 100 \mathrm{ml} \\
& \text { arterial blood } \\
& \mathrm{S}_{\mathrm{a}_{2}}=\mathrm{O}_{2} \text { saturation of } \mathrm{Hb} \\
& \text { Qs = blood flow through } \\
& \text { shunt }
\end{aligned}
$$

\section{Examples:}

$$
\begin{aligned}
\mathrm{P}_{\mathrm{a}_{\mathrm{CO}_{2}}=} & \underset{\text { partial pressure of }}{ } \mathrm{CO}_{2} \text { in a rterial blood } \\
\mathrm{C}_{\overline{\mathrm{v}}_{\mathrm{O}_{2}}=} & \begin{array}{l}
\mathrm{ml} \mathrm{O} \mathrm{O}_{2} \text { in } 100 \mathrm{ml} \text { mixed } \\
\text { venous blood }
\end{array}
\end{aligned}
$$




\section{APPENDIX B - TABULATED DATA}

Table 1 Effects of Air Blast on Arterial Oxygen $\left(\mathrm{Pa}_{\mathrm{O}_{2}}\right)$ and $\mathrm{CO}_{2}$ Tension $\left(\mathrm{PaCO}_{2}\right)$ for Dogs and Sheep Breathing Air or Oxygen

Table 2 Effects of Air Blast on Alveolar Oxygen $\left(\mathrm{P}_{\mathrm{AO}_{2}}\right)$ and $\mathrm{CO}_{2}$ Tension $\left(\mathrm{P}_{\mathrm{AO}_{2}}\right)$ for Dogs and Sheep Breathing Air or Oxygen

Table 3 Effects of Air Blast on Alveolar-Arterial Oxygen Difference $(\mathrm{A}-\mathrm{a}) \mathrm{O}_{2}$ and Arterial-End Tidal $\mathrm{CO}_{2}$ Difference (a-E.T.) $\mathrm{CO}_{2}$ for Dogs and Sheep Breathing Air or Oxygen

Table 4 Effects of Air Blast on Venous-Arterial Shunt (Q்s/ $\stackrel{\circ}{Q})$ and Blood $\mathrm{pH}$ for Dogs and Sheep

Table 5 Effects of Air Blast on $\mathrm{CO}_{2}$ Elimination $\left(\stackrel{\circ}{\mathrm{V}}_{\mathrm{CO}_{2}}\right)$, Oxygen Consumption $\left(\stackrel{\circ}{\mathrm{O}}_{2}\right)$, and Respiratory Exchange Ratio (R) for Dogs and Sheep Breathing Air

Table 6 Effects of Air Blast on Respiratory Rate (f), Inspiratory Minute Volume $\left(\stackrel{\circ}{\mathrm{V}}_{\mathrm{I}}\right)$, and Expiratory Minute Volume $\left(\stackrel{\circ}{\mathrm{V}}_{\mathrm{E}}\right)$ for Dogs and Sheep Breathing Air or Oxygen

Table 7 Effects of Air Blast on Total Alveolar Ventilation $\left(\stackrel{\circ}{V}_{A}\right)$ and Alveolar Dead Space Ventilation for Dogs and Sheep Breathing Air or Oxygen 
TABLE 1

EFFECTS OF AIR BLAST ON ARTERIAL OXYGEN $\left(\mathrm{P}_{\mathrm{a}_{0}}\right)$ AND $\mathrm{CO}_{2}$ TENSION $\left(\mathrm{P}_{\mathrm{a} \mathrm{CO}_{2}}\right)$ FOR DOGS AND SHEEP BREATHING AIR OR OXYGEN

\begin{tabular}{|c|c|c|c|c|c|c|c|c|c|c|c|c|}
\hline \multirow[b]{2}{*}{$\begin{array}{l}\text { Animal } \\
\text { Number }\end{array}$} & \multirow[b]{2}{*}{$\begin{array}{c}\text { Body Wt. } \\
\mathrm{Kg}_{\mathrm{g}}\end{array}$} & \multirow{2}{*}{$\begin{array}{c}\text { Reflected } \\
\text { Pressure } \\
\text { psi }\end{array}$} & \multirow{2}{*}{$\begin{array}{l}\text { Lung Weight, } \\
\text { Per Cent of } \\
\text { Body Weight }\end{array}$} & \multirow[b]{2}{*}{$\begin{array}{l}\text { Lung } \\
\text { Hemorrhage }\end{array}$} & \multicolumn{4}{|c|}{$\mathrm{P}_{\mathrm{aO}_{2}}, \mathrm{~mm} \mathrm{Hg}$. } & \multicolumn{4}{|c|}{$\mathrm{P}_{\mathrm{aCO}_{2}}, \mathrm{~mm} \mathrm{Hg}$. } \\
\hline & & & & & Pre & Post ${ }^{c}$ & 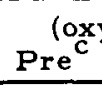 & Post ${ }^{c}$ & $\operatorname{Pre}^{\bar{d}}$ & Post ${ }^{c}$ & Pre & $\begin{array}{l}\text { (gen) } \\
\text { Post }\end{array}$ \\
\hline $\begin{array}{c}\text { Sheep } \\
381^{a} \\
401^{a} \\
372^{a} \\
386^{a} \\
366^{a} \\
570 \\
715 \\
646 \\
811 \\
794 \\
000 \\
771 \\
750 \\
187 \\
172 \\
384 a \\
821 \\
181 \\
487^{a} \\
825 \\
407^{a}\end{array}$ & $\begin{array}{l}39.5 \\
34.5 \\
38.6 \\
35.5 \\
39.1 \\
29.5 \\
37.6 \\
38.6 \\
43.0 \\
35.8 \\
41.4 \\
50.3 \\
42.7 \\
47.1 \\
42.3 \\
35.5 \\
38.5 \\
47.1 \\
35.0 \\
40.8 \\
42.7\end{array}$ & $\begin{array}{c}10 \\
17 \\
21 \\
21 \\
32^{b} \\
33 \\
34 \\
34 \\
35 \\
38 \\
40 \\
40 \\
40 \\
41 \\
42 \\
74 \mathrm{~b} \\
42 \\
43 \\
122 \mathrm{~b} \\
45 \\
48\end{array}$ & 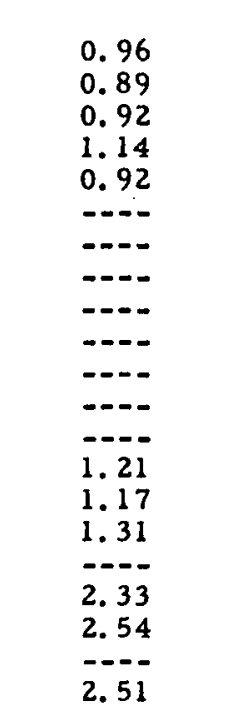 & $\begin{array}{l}\text { Confluent } \\
\text { Confluent } \\
\text { Confluent } \\
\text { Entire Lobes } \\
\text { Entire Lobes } \\
\text { Entire Lobes }\end{array}$ & $\begin{array}{l}53 \\
60 \\
49 \\
53 \\
41 \\
59 \\
47 \\
61 \\
63 \\
60 \\
70 \\
65 \\
68 \\
49 \\
68 \\
58 \\
58 \\
51 \\
34 \\
55 \\
60\end{array}$ & $\begin{array}{l}46 \\
52 \\
50 \\
58 \\
39 \\
42 \\
46 \\
41 \\
67 \\
49 \\
55 \\
47 \\
53 \\
62 \\
53 \\
47 \\
50 \\
53 \\
48 \\
48 \\
33\end{array}$ & $\begin{array}{l}354 \\
398 \\
370 \\
425 \\
377 \\
446 \\
388 \\
401 \\
384 \\
435 \\
412 \\
454 \\
438 \\
440 \\
428 \\
421 \\
459 \\
437 \\
-- \\
465 \\
389\end{array}$ & $\begin{array}{r}328 \\
468 \\
264 \\
152 \\
155 \\
276 \\
253 \\
140 \\
405 \\
332 \\
355 \\
394 \\
264 \\
358 \\
326 \\
167 \\
274 \\
82 \\
74 \\
353 \\
52\end{array}$ & $\begin{array}{l}36 \\
34 \\
37 \\
45 \\
30 \\
32 \\
31 \\
36 \\
35 \\
33 \\
38 \\
29 \\
24 \\
36 \\
28 \\
36 \\
32 \\
33 \\
34 \\
36 \\
36\end{array}$ & $\begin{array}{l}36 \\
40 \\
36 \\
41 \\
35 \\
35 \\
29 \\
37 \\
38 \\
34 \\
32 \\
28 \\
33 \\
31 \\
33 \\
37 \\
36 \\
33 \\
30 \\
31 \\
43\end{array}$ & $\begin{array}{l}20 \\
26 \\
48 \\
53 \\
46 \\
35 \\
36 \\
34 \\
35 \\
34 \\
49 \\
32 \\
30 \\
38 \\
28 \\
49 \\
39 \\
34 \\
-- \\
37 \\
43\end{array}$ & $\begin{array}{l}28 \\
21 \\
48 \\
52 \\
29 \\
33 \\
30 \\
54 \\
36 \\
37 \\
38 \\
31 \\
37 \\
33 \\
36 \\
46 \\
40 \\
34 \\
33 \\
36 \\
43\end{array}$ \\
\hline $\begin{array}{c}\text { Beagles } \\
D-56^{a} \\
D-19 \\
D-43 \\
D-22 \\
D-44 \\
D-53 a\end{array}$ & $\begin{array}{l}8.6 \\
9.5 \\
9.5 \\
9.1 \\
9.1 \\
4.8\end{array}$ & $\begin{array}{l}36 \\
37 \\
40 \\
39 \\
39 \\
42\end{array}$ & $\begin{array}{l}2.44 \\
1.47 \\
1.12 \\
3.85 \\
2.65 \\
3.77\end{array}$ & $\begin{array}{c}\text { Confluent } \\
\text { Confluent } \\
\text { Confluent } \\
\text { Entire Lobes } \\
\text { Entire Lobes } \\
\text { Entire Lobes }\end{array}$ & $\begin{array}{l}58 \\
81 \\
68 \\
73 \\
56 \\
62\end{array}$ & $\begin{array}{l}47 \\
63 \\
58 \\
60 \\
38 \\
51\end{array}$ & $\begin{array}{c}463 \\
452 \\
414 \\
-- \\
428 \\
422 \\
\end{array}$ & $\begin{array}{r}474 \\
260 \\
270 \\
152 \\
94 \\
92 \\
\end{array}$ & $\begin{array}{l}47 \\
22 \\
39 \\
32 \\
32 \\
32\end{array}$ & $\begin{array}{l}52 \\
28 \\
38 \\
36 \\
42 \\
43\end{array}$ & $\begin{array}{l}49 \\
25 \\
41 \\
37 \\
40 \\
34\end{array}$ & $\begin{array}{l}61 \\
32 \\
41 \\
41 \\
50 \\
51\end{array}$ \\
\hline
\end{tabular}

a a Anesthetized

$b=$ Exposed to $64-1 b$ charge of TNT

$c=$ Pre-and post-exposure 
TABLE 2

EFFECTS OF AIR BLAST ON ALVEOLAR OXYGEN ( $\left.\mathrm{P}_{\mathrm{A}_{2}}\right)$ AND $\mathrm{CO}_{2}$ TENSION $\left(\mathrm{PACO}_{2}\right)$ FOR DOGS AND SHEEP BREATHING AIR OR OXYGEN

\begin{tabular}{|c|c|c|c|c|c|c|c|c|c|c|c|c|}
\hline \multirow[b]{2}{*}{$\begin{array}{l}\text { Animal } \\
\text { Number }\end{array}$} & \multirow[b]{2}{*}{$\begin{array}{c}\text { Body Wt. } \\
\text { Kg. }\end{array}$} & \multirow{2}{*}{$\begin{array}{c}\text { Reflected } \\
\text { Pressure } \\
\text { psi }\end{array}$} & \multirow{2}{*}{$\begin{array}{l}\text { Lung Weight, } \\
\text { Per Cent of } \\
\text { Body Weight }\end{array}$} & \multirow[b]{2}{*}{$\begin{array}{c}\text { Lung } \\
\text { Hemorrhage }\end{array}$} & \multicolumn{4}{|c|}{$\mathrm{P}_{\mathrm{AO}_{2}}, \mathrm{~mm} \mathrm{Hg}$. } & \multicolumn{4}{|c|}{$\mathrm{P}_{\mathrm{ACO}_{2}}, \mathrm{~mm} \mathrm{Hg}}$. \\
\hline & & & & & Pre & Postc & $\begin{array}{r}\text { (oxy } \\
\text { Prec }\end{array}$ & $\begin{array}{l}\text { en) } \\
\text { Postc }\end{array}$ & $\operatorname{Pre}^{(a}$ & Postc & $\begin{array}{r}\text { lox } \\
\text { Pre }^{c}\end{array}$ & $\begin{array}{l}\text { (en) } \\
\text { Postc }\end{array}$ \\
\hline $\begin{array}{l}\text { Sheep } \\
381^{a} \\
401^{a} \\
372^{a} \\
386^{a} \\
366^{a} \\
570 \\
715 \\
646 \\
811 \\
794 \\
000 \\
771 \\
750 \\
187 \\
172 \\
384 a \\
821 \\
181 \\
487^{a} \\
825 \\
407^{a}\end{array}$ & $\begin{array}{l}39.5 \\
34.5 \\
38.6 \\
35.5 \\
39.1 \\
29.5 \\
37.6 \\
38.6 \\
43.0 \\
35.8 \\
41.4 \\
50.3 \\
42.7 \\
47.1 \\
42.3 \\
35.5 \\
38.5 \\
47.1 \\
35.0 \\
40.8 \\
42.7\end{array}$ & $\begin{array}{l}10 \\
17 \\
21 \\
21 \\
32^{b} \\
33 \\
34 \\
34 \\
35 \\
38 \\
40 \\
40 \\
40 \\
41 \\
42 \\
74 \mathrm{~b} \\
42 \\
43 \\
122 \mathrm{~b} \\
45 \\
48\end{array}$ & 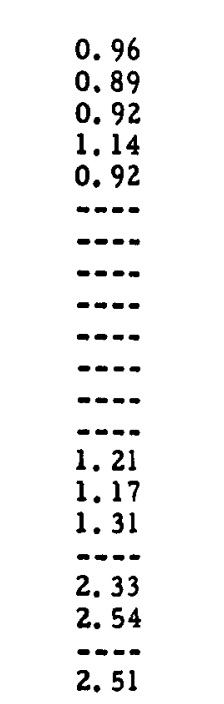 & $\begin{array}{l}\text { None } \\
\text { Petechial } \\
\text { Petechial } \\
\text { Small Isolated } \\
\text { Small Isolated } \\
\\
\text { Confluent } \\
\text { Confluent } \\
\text { Confluent } \\
\text { Entire Lobes } \\
\text { Entire Lobes } \\
\text { Entire Lobes }\end{array}$ & $\begin{array}{r}72 \\
85 \\
78 \\
65 \\
61 \\
68 \\
95 \\
83 \\
95 \\
78 \\
89 \\
96 \\
103 \\
79 \\
98 \\
72 \\
91 \\
74 \\
95 \\
97 \\
72\end{array}$ & $\begin{array}{l}75 \\
72 \\
73 \\
80 \\
78 \\
69 \\
88 \\
85 \\
86 \\
92 \\
79 \\
79 \\
90 \\
97 \\
90 \\
82 \\
90 \\
91 \\
74 \\
74 \\
90\end{array}$ & $\begin{array}{l}553 \\
546 \\
538 \\
523 \\
523 \\
533 \\
544 \\
534 \\
528 \\
549 \\
528 \\
545 \\
565 \\
540 \\
553 \\
479 \\
557 \\
547 \\
--2 \\
557 \\
527\end{array}$ & $\begin{array}{l}543 \\
552 \\
525 \\
519 \\
526 \\
535 \\
556 \\
526 \\
529 \\
553 \\
526 \\
553 \\
547 \\
557 \\
549 \\
512 \\
551 \\
556 \\
509 \\
553 \\
541\end{array}$ & $\begin{array}{l}38 \\
31 \\
34 \\
42 \\
38 \\
33 \\
13 \\
26 \\
20 \\
29 \\
24 \\
19 \\
18 \\
32 \\
17 \\
37 \\
19 \\
33 \\
23 \\
21 \\
35\end{array}$ & $\begin{array}{l}40 \\
37 \\
37 \\
32 \\
34 \\
31 \\
24 \\
23 \\
34 \\
22 \\
33 \\
25 \\
21 \\
19 \\
24 \\
32 \\
27 \\
23 \\
31 \\
17 \\
29\end{array}$ & $\begin{array}{l}19 \\
23 \\
32 \\
47 \\
36 \\
32 \\
16 \\
23 \\
36 \\
15 \\
42 \\
19 \\
11 \\
29 \\
14 \\
46 \\
19 \\
24 \\
-- \\
14 \\
30\end{array}$ & $\begin{array}{l}26 \\
18 \\
43 \\
52 \\
35 \\
28 \\
11 \\
32 \\
34 \\
14 \\
35 \\
12 \\
19 \\
15 \\
18 \\
38 \\
20 \\
12 \\
27 \\
16 \\
26\end{array}$ \\
\hline $\begin{array}{c}\text { Beagles } \\
D-56 a \\
D-19 \\
D-43 \\
D-22 \\
D-44 \\
D-53^{a}\end{array}$ & $\begin{array}{l}8.6 \\
9.5 \\
9.5 \\
9.1 \\
9.1 \\
4.8\end{array}$ & $\begin{array}{l}36 \\
37 \\
40 \\
39 \\
39 \\
42\end{array}$ & $\begin{array}{l}2.44 \\
1.47 \\
1.12 \\
3.85 \\
2.65 \\
3.77\end{array}$ & $\begin{array}{c}\text { Confluent } \\
\text { Confluent } \\
\text { Confluent } \\
\text { Entire Lobes } \\
\text { Entire Lobes } \\
\text { Entire Lobes }\end{array}$ & $\begin{array}{l}70 \\
92 \\
70 \\
83 \\
67 \\
70\end{array}$ & $\begin{array}{l}75 \\
92 \\
66 \\
88 \\
64 \\
85\end{array}$ & $\begin{array}{l}527 \\
545 \\
534 \\
542 \\
530 \\
535\end{array}$ & $\begin{array}{l}516 \\
546 \\
529 \\
530 \\
530 \\
543\end{array}$ & $\begin{array}{l}42 \\
21 \\
36 \\
28 \\
35 \\
38 \\
\end{array}$ & $\begin{array}{l}31 \\
21 \\
36 \\
27 \\
37 \\
28 \\
\end{array}$ & $\begin{array}{l}37 \\
24 \\
38 \\
27 \\
41 \\
34 \\
\end{array}$ & $\begin{array}{l}50 \\
24 \\
40 \\
32 \\
38 \\
26 \\
\end{array}$ \\
\hline
\end{tabular}

$a=$ Anesthetized
$b=$ Exposed to $64-1 \mathrm{~b}$ charge of TNT

c $=$ Pre-and post-exposure 
TABLE 3

EFFECTS OF AIR BLAST ON ALVEOLAR-ARTERIAL OXYGEN

DIFFERENCE (A-a) $0_{2}$ AND ARTERIAL-END TIDAL C0 $0_{2}$ DIFFERENCE (a-E.T.) $\mathrm{CO}_{2}$

FOR DOGS AND SHEEP BREATHING AIR OR OXYGEN

\begin{tabular}{|c|c|c|c|c|c|c|c|c|c|c|c|c|}
\hline \multirow[b]{2}{*}{$\begin{array}{l}\text { Animal } \\
\text { Number }\end{array}$} & \multirow[b]{2}{*}{$\begin{array}{l}\text { Body wt. } \\
\text { Kg. }\end{array}$} & \multirow{2}{*}{$\begin{array}{c}\text { Reflected } \\
\text { Pressure } \\
\text { psi } \\
\end{array}$} & \multirow{2}{*}{$\begin{array}{l}\text { Lung Weight, } \\
\text { Per Cent of } \\
\text { Body Weight }\end{array}$} & \multirow[b]{2}{*}{$\begin{array}{l}\text { Lung } \\
\text { Hemorrhage }\end{array}$} & \multicolumn{4}{|c|}{$(\mathrm{A}-\mathrm{a})_{0}, \mathrm{~mm} \mathrm{Hg}$} & \multicolumn{4}{|c|}{$(a-$ E.T. $) \mathrm{CO}_{2}, \mathrm{~mm} \mathrm{Hg.}$} \\
\hline & & & & & Pre & Postc & $\begin{array}{r}(0 x) \\
\text { Pre }^{c}\end{array}$ & ${ }_{\text {Post }} \mathrm{c}$ & $\operatorname{Pre}^{\overline{l a}}$ & Post ${ }^{c}$ & $\begin{array}{r}\text { loxy } \\
\text { Prec }\end{array}$ & $\begin{array}{l}\text { en) } \\
\text { Post }\end{array}$ \\
\hline $\begin{array}{c}\text { Sheep } \\
381^{a} \\
401^{a} \\
372^{a} \\
386^{a} \\
366^{a} \\
570 \\
715 \\
646 \\
811 \\
794 \\
000 \\
771 \\
750 \\
187 \\
172 \\
384 a \\
821 \\
181 \\
487^{a} \\
825 \\
407^{a}\end{array}$ & $\begin{array}{l}39.5 \\
34.5 \\
38.6 \\
35.5 \\
39.1 \\
29.5 \\
37.6 \\
38.6 \\
43.0 \\
35.8 \\
41.4 \\
50.3 \\
42.7 \\
47.1 \\
42.3 \\
35.5 \\
38.5 \\
47.1 \\
35.0 \\
40.8 \\
42.7\end{array}$ & $\begin{array}{l}10 \\
17 \\
21 \\
21 \\
32^{b} \\
33 \\
34 \\
34 \\
35 \\
38 \\
40 \\
40 \\
40 \\
41 \\
42 \\
74 b \\
42 \\
43 \\
122 \mathrm{~b} \\
45 \\
48\end{array}$ & 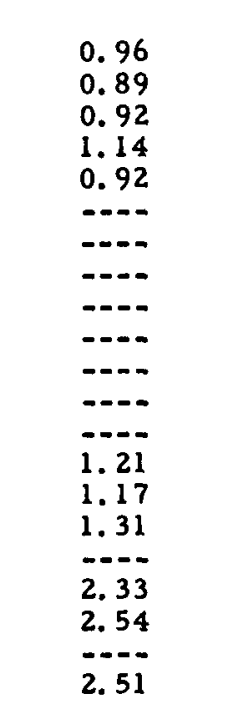 & $\begin{array}{l}\text { Confluent. } \\
\text { Confluent } \\
\text { Confluent } \\
\text { Entire Lobes } \\
\text { Entire Lobes } \\
\text { Entire Lobes }\end{array}$ & $\begin{array}{r}20 \\
24 \\
29 \\
12 \\
20 \\
8 \\
48 \\
22 \\
32 \\
18 \\
18 \\
30 \\
35 \\
30 \\
30 \\
13 \\
33 \\
23 \\
61 \\
42 \\
12\end{array}$ & $\begin{array}{l}30 \\
20 \\
23 \\
22 \\
39 \\
26 \\
42 \\
44 \\
19 \\
44 \\
24 \\
32 \\
37 \\
34 \\
38 \\
34 \\
40 \\
38 \\
26 \\
26 \\
56\end{array}$ & $\begin{array}{r}199 \\
148 \\
168 \\
98 \\
198 \\
87 \\
156 \\
133 \\
144 \\
114 \\
116 \\
91 \\
127 \\
100 \\
163 \\
58 \\
98 \\
110 \\
-2 \\
92 \\
138\end{array}$ & $\begin{array}{r}215 \\
84 \\
261 \\
367 \\
279 \\
259 \\
303 \\
386 \\
124 \\
221 \\
171 \\
159 \\
283 \\
199 \\
223 \\
345 \\
277 \\
474 \\
433 \\
200 \\
490\end{array}$ & $\begin{array}{r}-2 \\
2 \\
3 \\
2 \\
-8 \\
-1 \\
17 \\
10 \\
15 \\
4 \\
14 \\
10 \\
6 \\
4 \\
11 \\
-1 \\
13 \\
-1 \\
11 \\
15 \\
1\end{array}$ & $\begin{array}{r}-3 \\
3 \\
-1 \\
9 \\
0 \\
4 \\
6 \\
15 \\
4 \\
12 \\
-1 \\
3 \\
12 \\
12 \\
9 \\
5 \\
9 \\
10 \\
-1 \\
13 \\
14\end{array}$ & $\begin{array}{r}1 \\
3 \\
16 \\
6 \\
0 \\
2 \\
20 \\
11 \\
-2 \\
19 \\
7 \\
13 \\
18 \\
9 \\
14 \\
3 \\
20 \\
10 \\
-1 \\
22 \\
12\end{array}$ & $\begin{array}{r}2 \\
3 \\
5 \\
1 \\
-7 \\
5 \\
19 \\
22 \\
1 \\
23 \\
4 \\
19 \\
19 \\
18 \\
18 \\
8 \\
20 \\
21 \\
6 \\
20 \\
17\end{array}$ \\
\hline $\begin{array}{c}\text { Beagles } \\
D-56^{a} \\
D-19 \\
D-43 \\
D-22 \\
D-44 \\
D-53^{a}\end{array}$ & $\begin{array}{l}8.6 \\
9.5 \\
9.5 \\
9.1 \\
9.1 \\
4.8\end{array}$ & $\begin{array}{l}36 \\
37 \\
40 \\
39 \\
39 \\
42\end{array}$ & $\begin{array}{l}2.44 \\
1.47 \\
1.12 \\
3.85 \\
2.65 \\
3.77\end{array}$ & $\begin{array}{c}\text { Confluent } \\
\text { Confluent } \\
\text { Confluent } \\
\text { Entire Lobes } \\
\text { Entire Lobes } \\
\text { Entire Lobes }\end{array}$ & $\begin{array}{r}12 \\
11 \\
2 \\
11 \\
11 \\
8\end{array}$ & $\begin{array}{r}28 \\
30 \\
9 \\
28 \\
26 \\
34\end{array}$ & $\begin{array}{r}64 \\
93 \\
120 \\
-- \\
102 \\
113\end{array}$ & $\begin{array}{r}42 \\
286 \\
259 \\
377 \\
436 \\
451\end{array}$ & $\begin{array}{r}5 \\
0 \\
2 \\
4 \\
-3 \\
-6\end{array}$ & $\begin{array}{r}22 \\
7 \\
2 \\
8 \\
6 \\
15\end{array}$ & $\begin{array}{r}13 \\
1 \\
3 \\
9 \\
-2 \\
-1 \\
\end{array}$ & $\begin{array}{r}10 \\
8 \\
1 \\
8 \\
11 \\
25 \\
\end{array}$ \\
\hline
\end{tabular}

= Anesthetized $64-1 \mathrm{~b}$ charge of TNT

$c=$ Pre-and post-exposure 
TABLE 4

EFFECTS OF AIR BLAST ON VENOUS-ARTERIAL SHUNT (Q

AND BLOOD PH FOR DOGS AND SHEEP

\begin{tabular}{|c|c|c|c|c|c|c|c|c|c|c|}
\hline \multirow{3}{*}{$\begin{array}{l}\text { Animal } \\
\text { Number }\end{array}$} & \multirow{3}{*}{$\begin{array}{c}\text { Body Wt. } \\
\mathrm{Kg} .\end{array}$} & \multirow{3}{*}{$\begin{array}{c}\text { Reflected } \\
\text { Pressure } \\
\text { psi }\end{array}$} & \multirow{3}{*}{$\begin{array}{l}\text { Lung Weight, } \\
\text { Per Cent of } \\
\text { Body Weight }\end{array}$} & \multirow{3}{*}{$\begin{array}{c}\text { Lung } \\
\text { Hemorrhage }\end{array}$} & & & \multicolumn{4}{|c|}{$\mathrm{pH}$, Arterial } \\
\hline & & & & & \multicolumn{2}{|c|}{$\dot{\mathrm{Q}} \mathrm{s} / \dot{\mathrm{Q}}, \%$} & \multicolumn{2}{|c|}{$(a \mathrm{ir})$} & \multicolumn{2}{|c|}{ (oxygen) } \\
\hline & & & & & Pre & Post $t^{c}$ & Pre & Post $t^{c}$ & Pre & Post ${ }^{c}$ \\
\hline $\begin{array}{c}\text { Sheep } \\
381^{\mathrm{a}} \\
401^{\mathrm{a}} \\
372^{\mathrm{a}} \\
386^{\mathrm{a}} \\
366^{\mathrm{a}} \\
570 \\
715 \\
646 \\
811 \\
794 \\
000 \\
771 \\
750 \\
187 \\
172 \\
384^{\mathrm{a}} \\
821 \\
181 \\
487^{\mathrm{a}} \\
825 \\
407^{\mathrm{a}}\end{array}$ & $\begin{array}{l}39.5 \\
34.5 \\
38.6 \\
35.5 \\
39.1 \\
29.5 \\
37.6 \\
38.6 \\
43.0 \\
35.8 \\
41.4 \\
50.3 \\
42.7 \\
47.1 \\
42.3 \\
35.5 \\
38.5 \\
47.1 \\
35.0 \\
40.8 \\
42.7\end{array}$ & $\begin{array}{l}10 \\
17 \\
21 \\
21 \\
32 \mathrm{~b} \\
33 \\
34 \\
34 \\
35 \\
38 \\
40 \\
40 \\
40 \\
41 \\
42 \\
74^{b} \\
42 \\
43 \\
122^{b} \\
45 \\
48\end{array}$ & 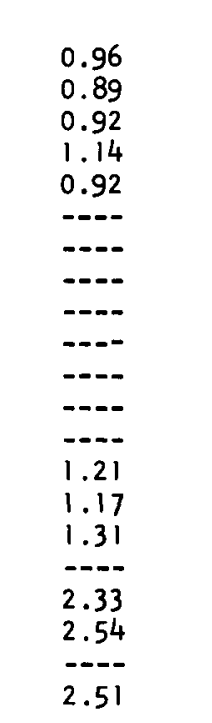 & $\begin{array}{l}\text { Confluent } \\
\text { Confluent } \\
\text { Confluent } \\
\text { Entire Lobes } \\
\text { Entire Lobes } \\
\text { Entire Lobes }\end{array}$ & $\begin{array}{r}11.0 \\
8.4 \\
9.4 \\
5.7 \\
8.3 \\
5.1 \\
8.8 \\
7.6 \\
8.2 \\
6.6 \\
6.7 \\
5.4 \\
7.3 \\
5.9 \\
6.5 \\
3.5 \\
5.7 \\
6.5 \\
--.- \\
5.4 \\
7.9\end{array}$ & $\begin{array}{r}11.7 \\
5.0 \\
13.9 \\
18.5 \\
15.4 \\
13.8 \\
15.8 \\
19.3 \\
7.2 \\
12.1 \\
9.6 \\
9.0 \\
14.9 \\
11.0 \\
12.1 \\
17.6 \\
14.6 \\
34.5 \\
34.8 \\
11.1 \\
53.4\end{array}$ & 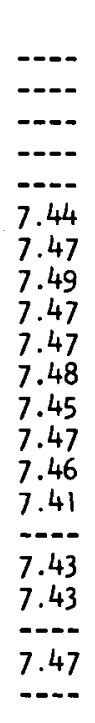 & $\begin{array}{l}---- \\
---- \\
---- \\
---- \\
---- \\
7.45 \\
7.46 \\
7.47 \\
7.45 \\
7.55 \\
7.46 \\
7.41 \\
7.49 \\
7.52 \\
7.54 \\
---. \\
7.43 \\
7.20 \\
--.- \\
7.46 \\
----\end{array}$ & 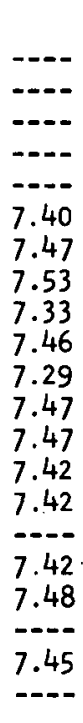 & $\begin{array}{l}-\cdot-- \\
---- \\
--- \\
---- \\
7.41 \\
7.40 \\
7.38 \\
7.38 \\
7.52 \\
7.44 \\
7.37 \\
7.47 \\
7.50 \\
7.50 \\
--.- \\
7.41 \\
7.18 \\
--.- \\
7.43 \\
-.--\end{array}$ \\
\hline $\begin{array}{c}\text { Beagles } \\
D-56^{a} \\
D-19 \\
D-43 \\
D-22 \\
D-44 \\
D-53^{a}\end{array}$ & $\begin{array}{l}8.6 \\
9.5 \\
9.5 \\
9.1 \\
9.1 \\
4.8\end{array}$ & $\begin{array}{l}36 \\
37 \\
40 \\
39 \\
39 \\
42\end{array}$ & $\begin{array}{l}2.44 \\
1.47 \\
1.12 \\
3.85 \\
2.65 \\
3.77\end{array}$ & $\begin{array}{l}\text { Confl uent } \\
\text { Confl uent } \\
\text { Confl uent } \\
\text { Entire Lobes } \\
\text { Entire Lobes } \\
\text { Entire Lobes }\end{array}$ & $\begin{array}{r}3.8 \\
5.5 \\
6.9 \\
--- \\
5.9 \\
6.5\end{array}$ & $\begin{array}{l}2.6 \\
15.1 \\
13.8 \\
19.0 \\
32.0 \\
31.5\end{array}$ & $\begin{array}{l}7.29 \\
--- \\
7.37 \\
---- \\
7.42 \\
7.39\end{array}$ & $\begin{array}{l}7.28 \\
--.- \\
7.35 \\
-.-2 \\
7.22 \\
7.23\end{array}$ & \begin{tabular}{l}
7.28 \\
\hdashline 7.35 \\
-1.35 \\
7.35
\end{tabular} & $\begin{array}{l}7.18 \\
--.- \\
7.24 \\
--.- \\
7.13 \\
7.17\end{array}$ \\
\hline
\end{tabular}

$a=$ Anesthetized

$b=$ Exposed to $64-1 b$ charge of TNT

$c=$ Pre- and post-exposure 
TABLE 5

EFFECTS OF AIR BLAST ON $\mathrm{C0}_{2}$ ELIMINATION $\left({ }_{\mathrm{V}} \mathrm{CO}_{2}\right)$, OXYGEN CONSUMPTION $\left({\stackrel{\circ}{0_{2}}}_{2}\right)$ AND RESPIRATORY EXCHANGE RATIO (R)

FOR DOGS AND SHEEP BREATHING AIR

\begin{tabular}{|c|c|c|c|c|c|c|c|c|c|c|}
\hline \multirow{2}{*}{$\begin{array}{l}\text { Animal } \\
\text { Number }\end{array}$} & \multirow{2}{*}{$\begin{array}{c}\text { Body Wt. } \\
\text { Kg. }\end{array}$} & \multirow{2}{*}{$\begin{array}{c}\text { Reflected } \\
\text { Pressure } \\
\text { psi }\end{array}$} & \multirow{2}{*}{$\begin{array}{l}\text { Lung Weight, } \\
\text { Per Cent of } \\
\text { Body Weight }\end{array}$} & \multirow{2}{*}{$\begin{array}{c}\text { Lung } \\
\text { Hemor rhage }\end{array}$} & \multicolumn{2}{|c|}{$\begin{array}{c}\stackrel{\circ}{\mathrm{V}_{\mathrm{CO}}}, \mathrm{ml} / \mathrm{min} \\
\mathrm{STPD} \\
\end{array}$} & \multicolumn{2}{|c|}{$\begin{array}{c}{\stackrel{\circ}{0_{2}}}_{2}, \mathrm{ml} / \mathrm{min} \\
\text { STPD }\end{array}$} & \multicolumn{2}{|c|}{$\mathbf{R}$} \\
\hline & & & & & Prec & Post ${ }^{c}$ & Prec & Post ${ }^{c}$ & Prec & Post ${ }^{c}$ \\
\hline $\begin{array}{l}\text { Sheep } \\
381^{a} \\
401^{a} \\
372^{a} \\
386^{a} \\
366^{a} \\
570 \\
715 \\
646 \\
811 \\
794 \\
000 \\
771 \\
750 \\
187 \\
172 \\
384^{a} \\
821 \\
181 \\
487^{a} \\
825 \\
407 a\end{array}$ & $\begin{array}{l}39.5 \\
34.5 \\
38.6 \\
35.5 \\
39.1 \\
29.5 \\
37.6 \\
38.6 \\
43.0 \\
35.8 \\
41.4 \\
50.3 \\
42.7 \\
47.1 \\
42.3 \\
35.5 \\
38.5 \\
47.1 \\
35.0 \\
40.8 \\
42.7\end{array}$ & $\begin{array}{c}10 \\
17 \\
21 \\
21 \\
32^{b} \\
33 \\
34 \\
34 \\
35 \\
38 \\
40 \\
40 \\
40 \\
41 \\
42 \\
74 b \\
42 \\
43 \\
122 b \\
45 \\
48\end{array}$ & 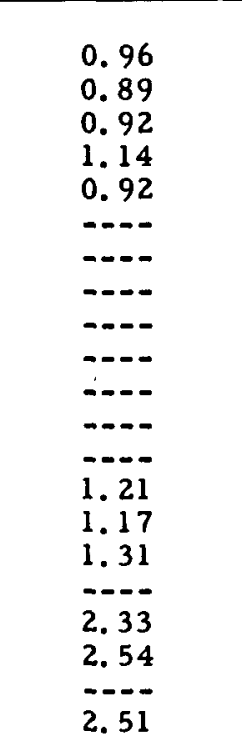 & $\begin{array}{l}\text { Confluent } \\
\text { Confluent } \\
\text { Confluent } \\
\text { Entire Lobes } \\
\text { Entire Lobes } \\
\text { Entire Lobes }\end{array}$ & $\begin{array}{r}151 \\
134 \\
109 \\
117 \\
78 \\
154 \\
135 \\
177 \\
172 \\
103 \\
151 \\
283 \\
213 \\
177 \\
146 \\
183 \\
195 \\
96 \\
240 \\
230 \\
82\end{array}$ & $\begin{array}{l}146 \\
109 \\
139 \\
100 \\
139 \\
137 \\
294 \\
194 \\
278 \\
226 \\
138 \\
203 \\
233 \\
178 \\
160 \\
166 \\
188 \\
120 \\
160 \\
130 \\
198\end{array}$ & $\begin{array}{l}199 \\
153 \\
143 \\
161 \\
131 \\
264 \\
258 \\
254 \\
211 \\
158 \\
214 \\
371 \\
227 \\
243 \\
198 \\
256 \\
336 \\
144 \\
261 \\
252 \\
119\end{array}$ & $\begin{array}{l}167 \\
150 \\
188 \\
135 \\
179 \\
238 \\
411 \\
322 \\
275 \\
291 \\
175 \\
357 \\
336 \\
230 \\
202 \\
209 \\
223 \\
162 \\
260 \\
396 \\
209\end{array}$ & $\begin{array}{l}0.76 \\
0.88 \\
0.76 \\
0.73 \\
0.60 \\
0.59 \\
0.52 \\
0.70 \\
0.82 \\
0.65 \\
0.70 \\
0.76 \\
0.94 \\
0.73 \\
0.75 \\
0.71 \\
0.58 \\
0.67 \\
0.92 \\
0.91 \\
0.69\end{array}$ & $\begin{array}{l}0.88 \\
0.73 \\
0.74 \\
0.74 \\
0.78 \\
0.57 \\
0.72 \\
0.60 \\
1.01 \\
0.78 \\
0.79 \\
0.57 \\
0.69 \\
0.77 \\
0.79 \\
0.79 \\
0.85 \\
0.74 \\
0.62 \\
0.33 \\
0.95\end{array}$ \\
\hline $\begin{array}{c}\text { Beagles } \\
D-56^{\mathrm{a}} \\
\mathrm{D}-19 \\
\mathrm{D}-43 \\
\mathrm{D}-22 \\
\mathrm{D}-44 \\
\mathrm{D}-53^{\mathrm{a}}\end{array}$ & $\begin{array}{l}8.6 \\
9.5 \\
9.5 \\
9.1 \\
9.1 \\
4.8\end{array}$ & $\begin{array}{l}36 \\
37 \\
40 \\
39 \\
39 \\
42\end{array}$ & $\begin{array}{l}2.44 \\
1.47 \\
1.12 \\
3.85 \\
2.65 \\
3.77\end{array}$ & $\begin{array}{c}\text { Confluent } \\
\text { Confluent } \\
\text { Confluent } \\
\text { Entire Lobes } \\
\text { Entire Lobes } \\
\text { Entire Lobes }\end{array}$ & $\begin{array}{l}34 \\
45 \\
60 \\
49 \\
50 \\
31\end{array}$ & $\begin{array}{l}30 \\
54 \\
44 \\
61 \\
39 \\
18\end{array}$ & $\begin{array}{l}42 \\
61 \\
90 \\
67 \\
82 \\
43\end{array}$ & $\begin{array}{l}49 \\
73 \\
70 \\
73 \\
65 \\
23\end{array}$ & $\begin{array}{l}0.83 \\
0.74 \\
0.67 \\
0.73 \\
0.62 \\
0.71\end{array}$ & $\begin{array}{l}0.62 \\
0.74 \\
0.63 \\
0.84 \\
0.60 \\
0.78\end{array}$ \\
\hline
\end{tabular}


TABLE 6

EFFECTS OF AIR BLAST ON RESPIRATORY RATE (f), INSPIRATORY MINUTE VOLUME ( $\left.\stackrel{\mathrm{V}}{I}_{\mathrm{I}}\right)$, AND EXPIRATORY MINUTE VOLUME $\left(\vee_{E}\right)$ FOR DOGS AND SHEEP BREATHING AIR OR OXYGEN

\begin{tabular}{|c|c|c|c|c|c|c|c|c|c|c|c|c|}
\hline \multirow[b]{2}{*}{$\begin{array}{l}\text { Animal } \\
\text { Number }\end{array}$} & \multirow[b]{2}{*}{$\begin{array}{c}\text { Body Wt. } \\
\text { Kg. }\end{array}$} & \multirow{2}{*}{$\begin{array}{l}\text { Reflected } \\
\text { Pressure } \\
\text { psi }\end{array}$} & \multirow{2}{*}{$\begin{array}{l}\text { Lung Weight, } \\
\text { Per Cent of } \\
\text { Body Weight }\end{array}$} & \multirow[b]{2}{*}{$\begin{array}{c}\text { Lung } \\
\text { Hemorrhage }\end{array}$} & \multicolumn{4}{|c|}{ f, Breaths $/ \mathrm{min}$} & \multicolumn{2}{|c|}{$\begin{array}{c}\mathrm{V}_{\mathrm{I}^{\prime}}, \quad \mathrm{L} / \mathrm{min} \\
\mathrm{BTPS}\end{array}$} & \multicolumn{2}{|c|}{$\begin{array}{l}\stackrel{\circ}{E}_{E}, L / m i n \\
\text { BTPS }\end{array}$} \\
\hline & & & & & \multicolumn{2}{|c|}{ (air) } & \multicolumn{2}{|c|}{ (oxygen) } & \multicolumn{2}{|c|}{ (air) } & \multicolumn{2}{|c|}{ (oxygen) } \\
\hline $\begin{array}{c}\text { Sheep } \\
381^{\mathrm{a}} \\
401^{\mathrm{a}} \\
372^{\mathrm{a}} \\
386^{\mathrm{a}} \\
366^{\mathrm{a}} \\
570 \\
715 \\
646 \\
811 \\
794 \\
000 \\
771 \\
750 \\
187 \\
172 \\
384 \mathrm{a} \\
821 \\
181 \\
487^{\mathrm{a}} \\
825 \\
407 \mathrm{a}\end{array}$ & $\begin{array}{l}39.5 \\
34.5 \\
38.6 \\
35.5 \\
39.1 \\
29.5 \\
37.6 \\
38.6 \\
43.0 \\
35.8 \\
41.4 \\
50.3 \\
42.7 \\
47.1 \\
42.3 \\
35.5 \\
38.5 \\
47.1 \\
35.0 \\
40.8 \\
42.7\end{array}$ & $\begin{array}{l}10 \\
17 \\
21 \\
21 \\
32^{b} \\
33 \\
34 \\
34 \\
35 \\
38 \\
40 \\
40 \\
40 \\
41 \\
42 \\
74 b \\
42 \\
43 \\
122^{b} \\
45 \\
48\end{array}$ & 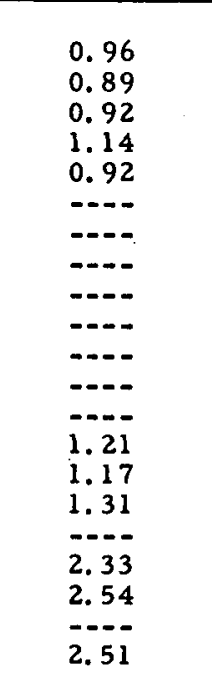 & $\begin{array}{l}\text { Confluent } \\
\text { Confluent } \\
\text { Confluent } \\
\text { Entire Lobes } \\
\text { Entire Lobes } \\
\text { Entire Lobes }\end{array}$ & $\begin{array}{r}36 \\
43 \\
31 \\
27 \\
21 \\
20 \\
110 \\
64 \\
60 \\
39 \\
64 \\
114 \\
114 \\
29 \\
63 \\
23 \\
66 \\
22 \\
34 \\
62 \\
26\end{array}$ & $\begin{array}{r}38 \\
43 \\
47 \\
36 \\
21 \\
35 \\
70 \\
85 \\
28 \\
92 \\
34 \\
76 \\
133 \\
62 \\
48 \\
36 \\
46 \\
46 \\
31 \\
90 \\
56\end{array}$ & $\begin{array}{r}17 \\
13 \\
17 \\
25 \\
18 \\
21 \\
97 \\
57 \\
27 \\
100 \\
57 \\
89 \\
146 \\
38 \\
84 \\
14 \\
71 \\
42 \\
-7 \\
96 \\
21\end{array}$ & $\begin{array}{r}11 \\
14 \\
34 \\
53 \\
33 \\
30 \\
132 \\
49 \\
67 \\
92 \\
47 \\
102 \\
151 \\
78 \\
65 \\
32 \\
39 \\
50 \\
34 \\
98 \\
59\end{array}$ & $\begin{array}{r}9.54 \\
10.97 \\
9.29 \\
8.03 \\
4.79 \\
12.70 \\
36.10 \\
19.46 \\
20.30 \\
10.81 \\
19.56 \\
38.16 \\
26.26 \\
14.41 \\
21.37 \\
10.47 \\
31.54 \\
7.28 \\
13.96 \\
24.38 \\
7.64\end{array}$ & $\begin{array}{r}10.22 \\
9.47 \\
10.33 \\
10.24 \\
6.49 \\
11.55 \\
34.50 \\
21.75 \\
15.12 \\
27.30 \\
11.76 \\
23.84 \\
32.27 \\
23.28 \\
16.62 \\
10.44 \\
21.84 \\
13.54 \\
10.89 \\
27.90 \\
21.94\end{array}$ & $\begin{array}{r}15.33 \\
11.88 \\
7.69 \\
7.60 \\
9.99 \\
15.79 \\
31.53 \\
17.33 \\
9.43 \\
23.40 \\
24.93 \\
24.91 \\
35.44 \\
18.43 \\
37.80 \\
6.90 \\
6.66 \\
7.18 \\
--. \\
22.14 \\
4.77\end{array}$ & $\begin{array}{r}9.58 \\
6.93 \\
9.12 \\
-- \\
9.88 \\
12.00 \\
32.98 \\
18.91 \\
21.73 \\
28.18 \\
15.43 \\
22.18 \\
34.99 \\
30.76 \\
18.78 \\
8.46 \\
22.31 \\
17.90 \\
9.13 \\
20.82 \\
21.49\end{array}$ \\
\hline $\begin{array}{c}\text { Beagles } \\
D-56^{a} \\
D-19 \\
D-43 \\
D-22 \\
D-44 \\
D-53^{a}\end{array}$ & $\begin{array}{l}8.6 \\
9.5 \\
9.5 \\
9.1 \\
9.1 \\
4.8\end{array}$ & $\begin{array}{l}36 \\
37 \\
40 \\
39 \\
39 \\
42\end{array}$ & $\begin{array}{l}2.44 \\
1.47 \\
1.12 \\
3.85 \\
2.65 \\
3.77\end{array}$ & $\begin{array}{c}\text { Confluent } \\
\text { Confluent } \\
\text { Confluent } \\
\text { Entire Lobes } \\
\text { Entire Lobes } \\
\text { Entire Lobes }\end{array}$ & $\begin{array}{l}28 \\
24 \\
18 \\
12 \\
22 \\
14\end{array}$ & $\begin{array}{l}45 \\
42 \\
21 \\
20 \\
54 \\
50\end{array}$ & $\begin{array}{l}15 \\
20 \\
16 \\
11 \\
23 \\
11\end{array}$ & $\begin{array}{l}27 \\
29 \\
24 \\
17 \\
59 \\
48\end{array}$ & $\begin{array}{l}4.13 \\
6.18 \\
4.83 \\
4.19 \\
4.24 \\
3.52\end{array}$ & $\begin{array}{l}6.10 \\
8.22 \\
3.77 \\
6.01 \\
5.78 \\
8.40\end{array}$ & $\begin{array}{l}3.75 \\
4.71 \\
3.60 \\
3.65 \\
5.94 \\
3.31\end{array}$ & $\begin{array}{l}4.06 \\
9.70 \\
4.51 \\
4.92 \\
7.26 \\
--\end{array}$ \\
\hline
\end{tabular}

$a=$ Anesthetized

$b=$ Exposed to $64-1 b$ charge of TNT

$c=$ Pre- and post-exposure 
TABLE 7

EFFECTS OF AIR BLAST ON TOTAL ALVEOLAR VENTILATION ( ${ }^{\circ}$ ) AND ALVEOLAR DEAD SPACE VENTILATION FOR DOGS AND SHEEP

BREATHING AIR OR OXYGEN

\begin{tabular}{|c|c|c|c|c|c|c|c|c|c|c|c|c|}
\hline \multirow[b]{2}{*}{$\begin{array}{l}\text { Animal } \\
\text { Number }\end{array}$} & \multirow[b]{2}{*}{$\begin{array}{c}\text { Body Wt. } \\
\text { Kg. }\end{array}$} & \multirow{2}{*}{$\begin{array}{l}\text { Reflected } \\
\text { Pressure } \\
\text { psi }\end{array}$} & \multirow{2}{*}{$\begin{array}{l}\text { Lung Weight, } \\
\text { Per Cent of } \\
\text { Body Weight }\end{array}$} & \multirow[b]{2}{*}{$\begin{array}{l}\text { Lung } \\
\text { Hemorrhage }\end{array}$} & \multicolumn{4}{|c|}{$\stackrel{\circ}{\mathrm{A}}, \mathrm{L} / \mathrm{min}, \mathrm{BTPS}$} & \multicolumn{4}{|c|}{ Alveolar Dead Space, $\%$} \\
\hline & & & & & Pre $e^{c^{\prime}}$ & Post $c$ & Pre $\operatorname{lox}^{\operatorname{lox}}$ & Post ${ }^{c}$ & $\mathrm{Pre}^{\mathrm{c}^{\mathrm{a}}}$ & Post ${ }^{c}$ & $\operatorname{Pre}^{\stackrel{\text { lox }}{c}}$ & ${ }_{\text {Post }}{ }^{\text {en) }}$ \\
\hline $\begin{array}{c}\text { Sheep } \\
381^{a} \\
401^{a} \\
372^{a} \\
386^{a} \\
366^{a} \\
570 \\
715 \\
646 \\
811 \\
794 \\
000 \\
771 \\
750 \\
187 \\
172 \\
384 a \\
821 \\
181 \\
487^{a} \\
825 \\
407^{a}\end{array}$ & $\begin{array}{l}39.5 \\
34.5 \\
38.6 \\
35.5 \\
39.1 \\
29.5 \\
37.6 \\
38.6 \\
43.0 \\
35.8 \\
41.4 \\
50.3 \\
42.7 \\
47.1 \\
42.3 \\
35.5 \\
38.5 \\
47.1 \\
35.0 \\
40.8 \\
42.7\end{array}$ & $\begin{array}{l}10 \\
17 \\
21 \\
21 \\
32^{\mathrm{b}} \\
33 \\
34 \\
34 \\
35 \\
38 \\
40 \\
40 \\
40 \\
41 \\
42 \\
74 \mathrm{~b} \\
42 \\
43 \\
122^{\mathrm{b}} \\
45 \\
48\end{array}$ & 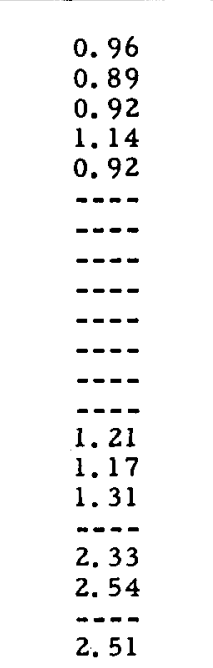 & $\begin{array}{l}\text { Confluent } \\
\text { Confluent } \\
\text { Confluent } \\
\text { Entire Lobes } \\
\text { Entire Lobes } \\
\text { Entire Lobes }\end{array}$ & $\begin{array}{r}3.44 \\
3.69 \\
2.78 \\
2.40 \\
1.79 \\
4.07 \\
8.73 \\
5.98 \\
7.41 \\
3.13 \\
5.52 \\
12.90 \\
10.48 \\
4.84 \\
7.75 \\
4.34 \\
8.95 \\
2.50 \\
9.00 \\
9.31 \\
2.03\end{array}$ & $\begin{array}{r}3.21 \\
2.57 \\
3.30 \\
2.73 \\
3.53 \\
3.82 \\
10.75 \\
7.49 \\
7.16 \\
8.95 \\
3.66 \\
7.03 \\
9.52 \\
8.08 \\
5.71 \\
4.59 \\
6.13 \\
4.62 \\
4.50 \\
6.48 \\
6.03\end{array}$ & $\begin{array}{r}10.28 \\
7.08 \\
1.41 \\
2.26 \\
2.04 \\
5.97 \\
7.90 \\
4.99 \\
3.57 \\
8.56 \\
8.20 \\
7.88 \\
20.77 \\
3.73 \\
16.00 \\
2.12 \\
1.85 \\
2.30 \\
-.- \\
7.90 \\
1.03\end{array}$ & $\begin{array}{r}5.65 \\
3.79 \\
3.04 \\
-- \\
3.98 \\
4.31 \\
13.75 \\
8.79 \\
6.86 \\
16.24 \\
4.81 \\
9.16 \\
11.49 \\
8.65 \\
6.12 \\
3.50 \\
7.59 \\
7.66 \\
2.93 \\
7.73 \\
6.44\end{array}$ & $\begin{array}{r}-5.6 \\
6.5 \\
8.0 \\
5.3 \\
-28.0 \\
-3.3 \\
56.5 \\
27.7 \\
42.0 \\
12.1 \\
37.2 \\
35.1 \\
26.6 \\
12.4 \\
40.7 \\
-1.6 \\
41.3 \\
-2.5 \\
31.9 \\
40.6 \\
3.0\end{array}$ & $\begin{array}{r}-9.0 \\
8.0 \\
-2.0 \\
22.1 \\
0.9 \\
10.4 \\
18.9 \\
39.5 \\
11.1 \\
36.0 \\
-3.8 \\
11.6 \\
36.2 \\
39.0 \\
26.7 \\
13.7 \\
25.4 \\
31.9 \\
-3.7 \\
43.0 \\
33.0\end{array}$ & $\begin{array}{r}6.3 \\
12.1 \\
33.0 \\
10.4 \\
-0.7 \\
6.8 \\
54.8 \\
32.6 \\
-4.4 \\
55.4 \\
13.8 \\
41.2 \\
62.5 \\
22.6 \\
49.8 \\
5.9 \\
51.5 \\
29.8 \\
-.- \\
60.4 \\
26.0\end{array}$ & $\begin{array}{r}6.8 \\
15.0 \\
10.0 \\
-- \\
-25.3 \\
14.4 \\
62.4 \\
41.4 \\
3.4 \\
61.1 \\
9.0 \\
60.7 \\
49.7 \\
53.6 \\
49.6 \\
18.3 \\
49.5 \\
62.7 \\
18.5 \\
54.6 \\
39.0\end{array}$ \\
\hline $\begin{array}{c}\text { Beagles } \\
D-56^{\mathrm{a}} \\
\mathrm{D}-19 \\
\mathrm{D}-43 \\
\mathrm{D}-22 \\
\mathrm{D}-44 \\
\mathrm{D}-53^{\mathrm{a}}\end{array}$ & $\begin{array}{l}8.6 \\
9.5 \\
9.5 \\
9.1 \\
9.1 \\
4.8\end{array}$ & $\begin{array}{l}36 \\
37 \\
40 \\
39 \\
39 \\
42\end{array}$ & $\begin{array}{l}2.44 \\
1.47 \\
1.12 \\
3.85 \\
2.65 \\
3.77\end{array}$ & $\begin{array}{c}\text { Confluent } \\
\text { Confluent } \\
\text { Confluent } \\
\text { Entire Lobes } \\
\text { Entire Lobes } \\
\text { Entire Lobes }\end{array}$ & $\begin{array}{l}0.71 \\
1.84 \\
1.44 \\
1.52 \\
1.24 \\
0.71\end{array}$ & $\begin{array}{l}0.86 \\
2.19 \\
1.06 \\
1.96 \\
0.92 \\
0.55\end{array}$ & $\begin{array}{l}0.59 \\
1.48 \\
0.55 \\
1.51 \\
1.04 \\
0.85\end{array}$ & $\begin{array}{l}0.39 \\
1.46 \\
1.28 \\
1.38 \\
1.06 \\
-.\end{array}$ & $\begin{array}{r}10.6 \\
1.9 \\
6.6 \\
11.1 \\
-10.2 \\
-19.2 \\
\end{array}$ & $\begin{array}{r}41.3 \\
24.4 \\
3.9 \\
23.9 \\
13.3 \\
34.9 \\
\end{array}$ & $\begin{array}{r}25.4 \\
2.9 \\
7.6 \\
25.0 \\
-3.9 \\
-1.8 \\
\end{array}$ & $\begin{array}{r}17.0 \\
26.7 \\
1.6 \\
20.1 \\
23.0 \\
--- \\
\end{array}$ \\
\hline
\end{tabular}

$a=$ Anesthetized

$\mathrm{b}=$ Exposed to $64-1 \mathrm{~b}$ charge of TNT

$c=$ Pre-and post-exposure 


\section{APPENDIX C}

DISTRIBUTION

Copy

Director

Armed Forces Institute of Pathology

Walter Reed Army Medical Center

14th Street and Alaska Avenue

Washington, D. C. 20012

Director

Armed Forces Radiobiology Research Institute

Defense Atomic Support Agency

National Naval Medical Center

Bethesda, Maryland 20014

Assistant to the Secretary of Defense (Atomic Energy)

Washington, D.C. 20301

ATTN: Document Control

Director

Defense Atomic Support Agency

Washington, D. C. 20305

ATTN: APTL (Technical Library)

ATTN: STMD

Administrator

Defense Documentation Center

Cameron Station, Building 5

Alexandria, Virginia 22314

ATTN: Document Control

Director of Defense Research and Engineering

Washington, D. C. 20301

ATTN: Asst. Director (Nuclear Programs)

Commander

Field Command

Defense Atomic Support Agency

Sandia Base

Albuquerque, New Mexico 87115

ATTN: Technical Library FCTG-5 
DISTRIBUTION (Continued):

Copy

Commander

Test Command

Defense Atomic Support Agency

Sandia Base

Albuquerque, New Mexico 87115

ATTN: Document Control

Director

Weapons Systems Evaluation Group

Washington, D. C. 20305

Chief

Army CDC Medical Service Agency

Fort Sam Houston, Texas 78234

Chief

Army Combat Developments Command

Chemical-Biological-Radiological Agency

Fort McClellan, Alabama 36205

ATTN: CBR

Commanding Officer

Army Combat Developments Command

Institute of Nuclear Studies

Fort Bliss, Texas 79916

ATTN: Charles N. Davidson

Commandant

Army Medical Field Service School

Brooke Army Medical Center

Fort Sam Houston, Texas $\mathbf{7 8 2 3 4}$

Director

Army Nuclear Effects Laboratory

Edgewood Arsenal, Maryland 21010

ATTN: Technical Library

Chief

Army Research Office

Life Sciences Division

3045 Columbia Pike

Arlington, Virginia 22210 
DISTRIBUTION (Continued):

Copy

Director

Ballistic Research Laboratories

Aberdeen Proving Ground, Maryland 21005

ATTN: AMXBR-TB, J. Meszarus

Chief of Research and Development

Department of the Army

Washington, D. C. 20310

ATTN: NCB Division

Director of Civil Defense

Department of the Army

Washington, D. C. 20310

ATTN: Asst. Director for Research

Commanding General

Medical Research and Development Command

Washington, D. C. 20314

ATTN: NBC Sciences Division

Safeguard System Manager

Safeguard System Office 1320 Wilson Blvd.

Arlington, Virginia 22209

ATTN: Plans Division

The Surgeon General

Department of the Army

Washington, D.C. 20314

Director

Walter Reed Army Institute of Research

Walter Reed Army Medical Center

Washington, D. C. 20012

ATTN: Documents Library

Chief

Bureau of Medicine and Surgery

Navy Department

Washington, D.C. 20390 
DISTRIBUTION (Continued):

Copy

Chief of Naval Material

Navy Department

Washington, D. C. 20360

ATTN: MAT 031

ATTN: Code 0312D, I. Jaffe

Chief of Naval Operations

Navy Department

Washington, D.C. 20350

ATTN: OP-752D

Chief of Naval Research

Navy Department

Washington, D. C. 20360

ATTN: Code 402

ATTN: Code 418 , Dr. T. P. Quinn

Commanding Officer

Naval Aero space Medical Institute

Naval Aerospace Medical Center

Pensacola, Florida 32512

Commander

Naval Air Development Center

Johnsville

Warminster, Pennsylvania 18974

ATTN: Dr. Chisum

Commander

Naval Air Systems Command

Headquarters

Washington, D. C. 20360

ATTN: AIR 5381

ATTN: AIR 350

Commanding Officer

Naval Medical Research Institute

National Naval Medical Center

Bethesda, Maryland 20014 
DISTRIBUTION (Continued):

Commander

Naval Ordnance Laboratory

Silver Spring, Maryland 20910

ATTN: Code 121 (D. M. Meredith)

ATTN: Code 210 (Dr. Scanlon)

ATTN: W. L. Derksen

Director

Naval Research Laboratory

Washington, D. C. 20390

ATTN: Technical Library

Commander

Naval Ship Research and Development Center

Washington, D. C. 20007

ATTN: Library

Commanding Officer

Naval Submarine Medical Center

Naval Submarine Base-New London

Groton, Connecticut 06340

Commanding Officer

Naval Weapons Evaluation Facility

Kirtland Air Force Base

Albuquerque, New Mexico 87117

ATTN: Document Control

Commander

Naval Weapons Laboratory

Dahlgren, Virginia 22448

ATTN: Mr. W. Culbertson

Aerospace Medical Division, AFSC

Brooks AFB, Texas 78235

ATTN: AMBR

AF Director of Nuclear Safety

Kirtland AFB, New Mexico 87117

AF Office of Scientific Research, OAR 1400 Wilson Blvd.

Arlington, Virginia 22209

ATTN: Technical Library 
DISTRIBUTION (Continued):

Copy

AF Special Weapons Center, AFSC

Kirtland AFB, New Mexico 87117

ATTN: SWTSX, Survivability/Vulnerability Branch

AF Weapons Laboratory, AFSC

Kirtland AFB, New Mexico 87117

ATTN: Chief, WLBR (Biophysics Div.)

Headquarters

Air Force Systems Command

Andrews AFB

Washington, D. C. 20331

ATTN: SCBB

Headquarters USAF

2

Washington, D. C. 20330

ATTN: AFRDQSN (Strategic and Defense Forces, Nuclear Ordnance Division)

ATTN: AFRDDG (Scientific and Technical Division, Director of Development)

USAF Medical Service School

Sheppard AFB, Texas 76311

USAF Radiological Health Laboratory, AFLC

Wright-Patterson AFB, Ohio 45433

USAF School of Aerospace Medicine, AFSC

Brooks AFB, Texas 78235

ATTN: SMBR

ATTN: SMKOR

6570th Aerospace Medical Research Labs., AFSC

Wright-Patterson AFB, Ohio 45433

6571st Aeromedical Research Laboratory, AFSC

Holloman AFB, New Mexico 88330

Battelle Memorial Institute

Pacific Northwest Laboratory

P. O. Box 999

Richland, Washington 99352

ATTN: Dr. K. H. Larson 
DISTRIBUTION (Continued):

Brookhaven National Laboratory

Copy

P. O. Box 150

Upton, Long Island, New York 11973

ATTN: Document Control for Information Division

ATTN: Document Control for Classified Document Section

Los Alamos Scientific Laboratory

P. O. Box 1663

Los Alamos, New Mexico 87544

ATTN: Document Control for DASA Liaison Office, LASL

ATTN: Document Control for LASL Library, Serials Librarian

U.S. Atomic Energy Commission

Division of Tech. Info Ext.

P. O. Box 62

Oak Ridge, Tennessee 37830

ATTN: Document Control

U.S. Atomic Energy Commission

Washington, D. C. 20545

ATTN: Document Control for Reports Section

ATTN: Document Control for Biological and Medical Division, L. J. Deal

ATTN: Document Control for Biological and Medical Division,

H. D. Bruner

Assistant General Manager for Military Applications

U.S. Atomic Energy Commission

Washington, D. C. 20545

ATTN: Document Control for Research and Development Branch

U.S. Atomic Energy Commission

New York Operations Office

376 Hudson Street

New York, New York 10014

ATTN: Document Control for Dr. J. H. Harley, HASL

Union Carbide Corporation

Nuclear Division

Oak Ridge National Laboratory

P. O. Box X

Oak Ridge, Tennessee 37830

ATTN: Document Control for J. Auxier, Health Physics Department ATTN: Document Control for Atomic and Mol. Processes Info Center 
DISTRIBUT ION (Continued):

University of California

Lawrence Radiation Laboratory

Technical Information Division

P. O. Box 808

Livermore, California 94550

ATTN: Technical Library (Inner Label Only)

National Aeronautics and Space Administration Representative

Scientific and Technical Information Facility

P. O. Box 33

College Park, Maryland 20740

ATTN: SAK/DLA-385

Department of Transportation

National Highway Safety Bureau Research Center

6th and D Streets, S.W.

Washington, D. C. 20591

ATTN: Mr. A. Hirsch

National Library of Medicine

Accessions Branch

8600 Wisconsin Avenue

Bethesda, Maryland 20014

Cincinnati General Hospital

Radioisotope Laboratory

Cincinnati, Ohio $\mathbf{4 5 2 2 9}$

ATTN: Dr. E. L. Saenger

General Electric Company

Tempo-Center for Advanced Studies

816 State Street

Santa Barbara, California 93102

ATTN: DASA Information and Analysis Center

Lovelace Foundation for Medical Education and Research

5200 Gibson Blvd., S.E.

Albuquerque, New Mexico 87108

ATTN: Dr. Clayton White

ATTN: Dr. Robert K. Jones 
DISTRIBUTION (Continued):

Copy

Medical College of South Carolina

Department of Surgery

55 Doughty Street

Charleston, South Carolina 29403

ATTN: Dr. M. S. Rittenbury

New York State Veterinary College

Cornell University

Department of Physical Biology

Ithaca, New York 14850

ATTN: Dr. Comar

Technology, Inc.

Life Sciences Division

8531 N. New Braunfels Avenue

San Antonio, Texas 78217

University of California

San Francisco Medical Center

Department of Upthamology

San Francisco, California 94122

ATTN: Dr. Severin

Virginia Commonwealth University

Medical College of Virginia

Health Science Division

1200 E. Broad Street

Richmond, Virginia 23219

ATTN: Department of Biophysics 


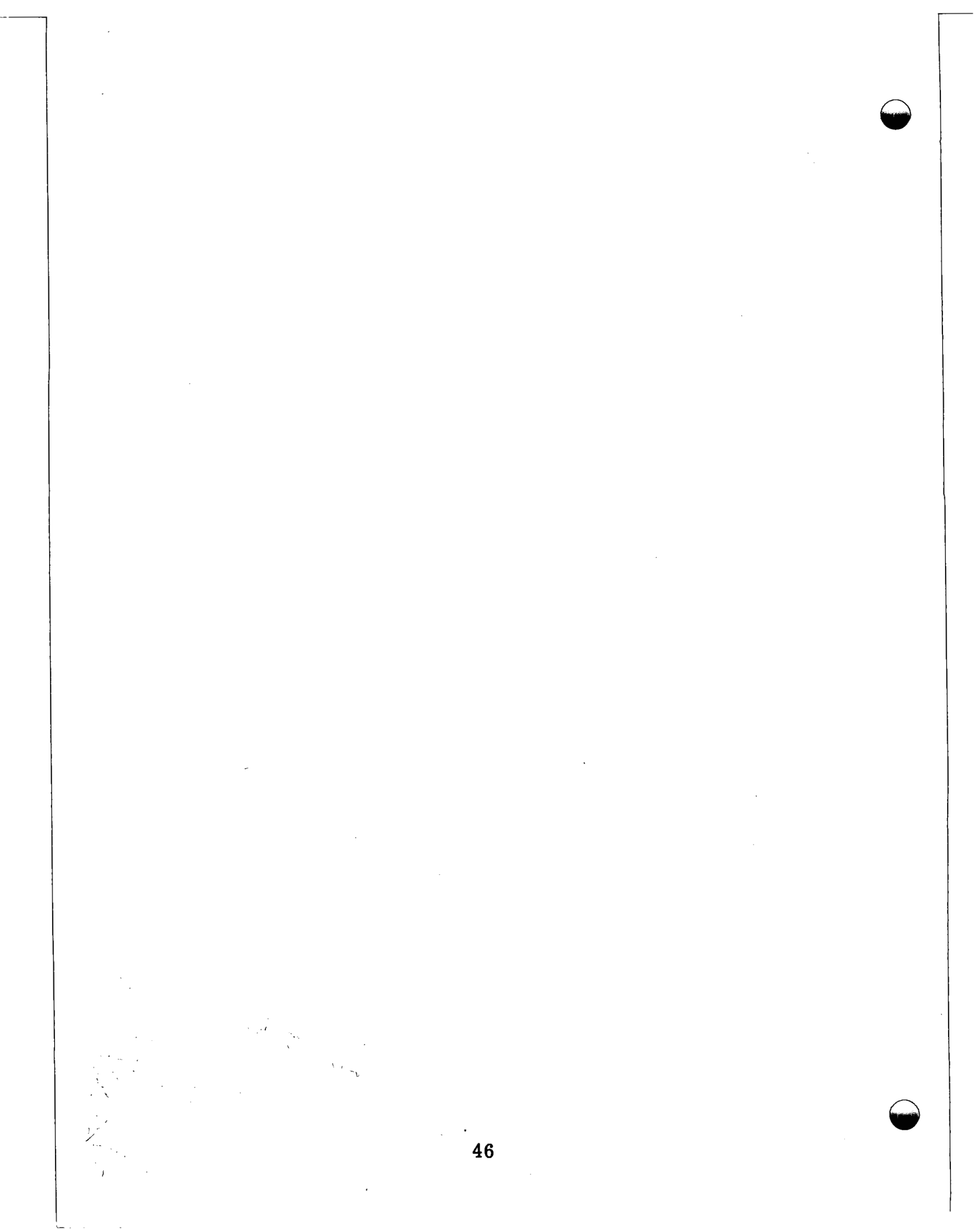


Unclas sified

Security Classification

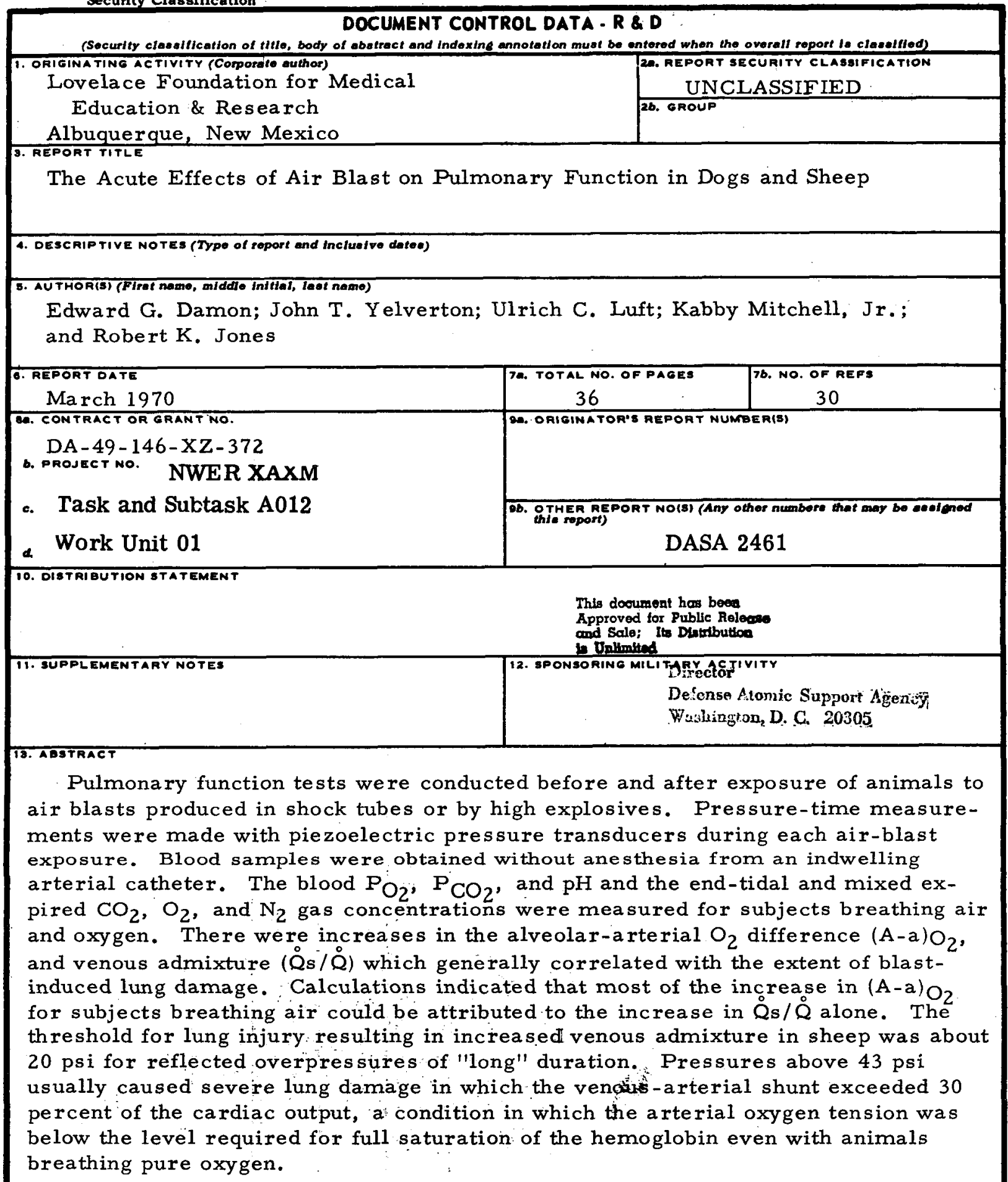




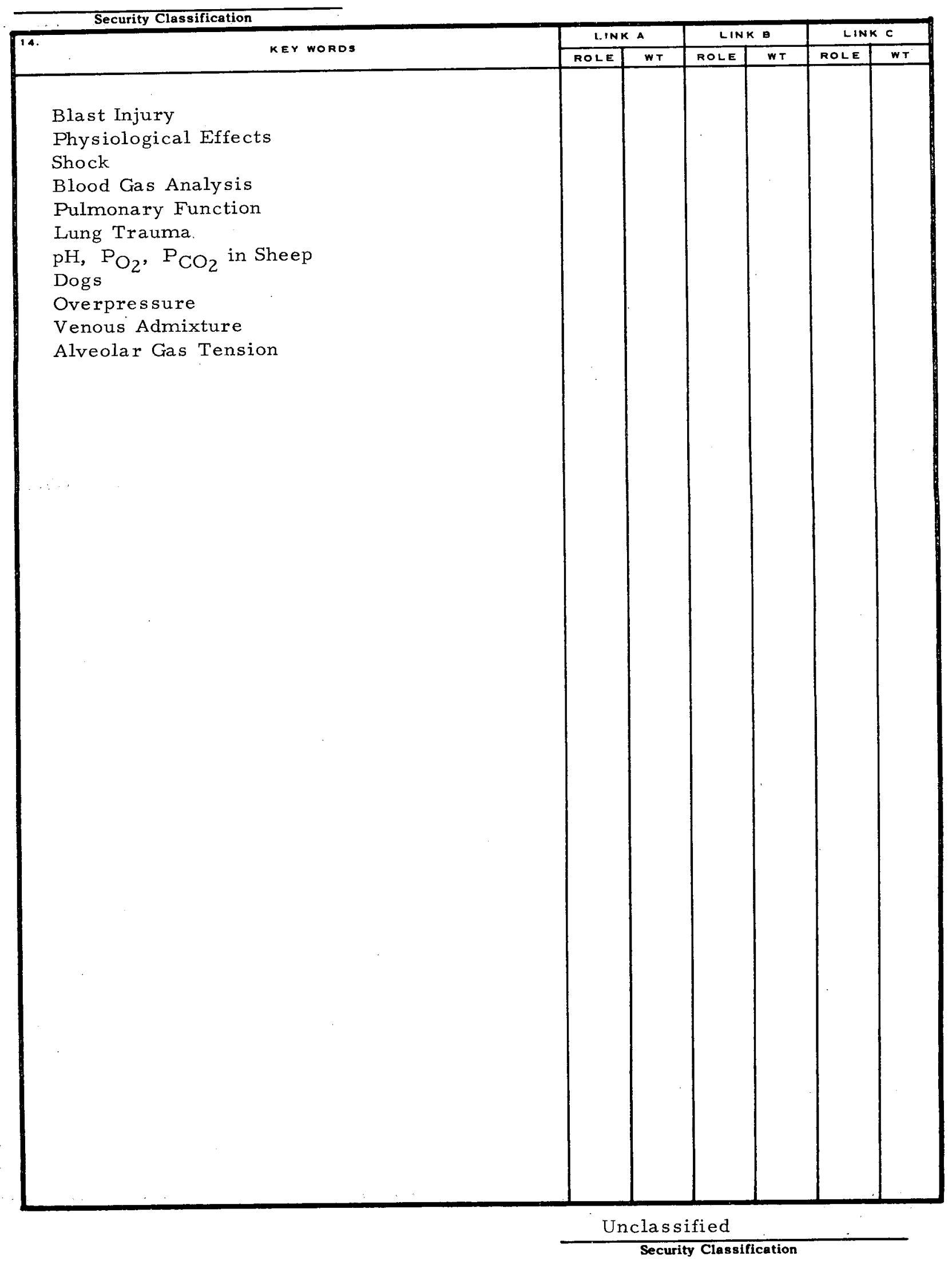

